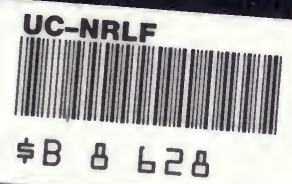




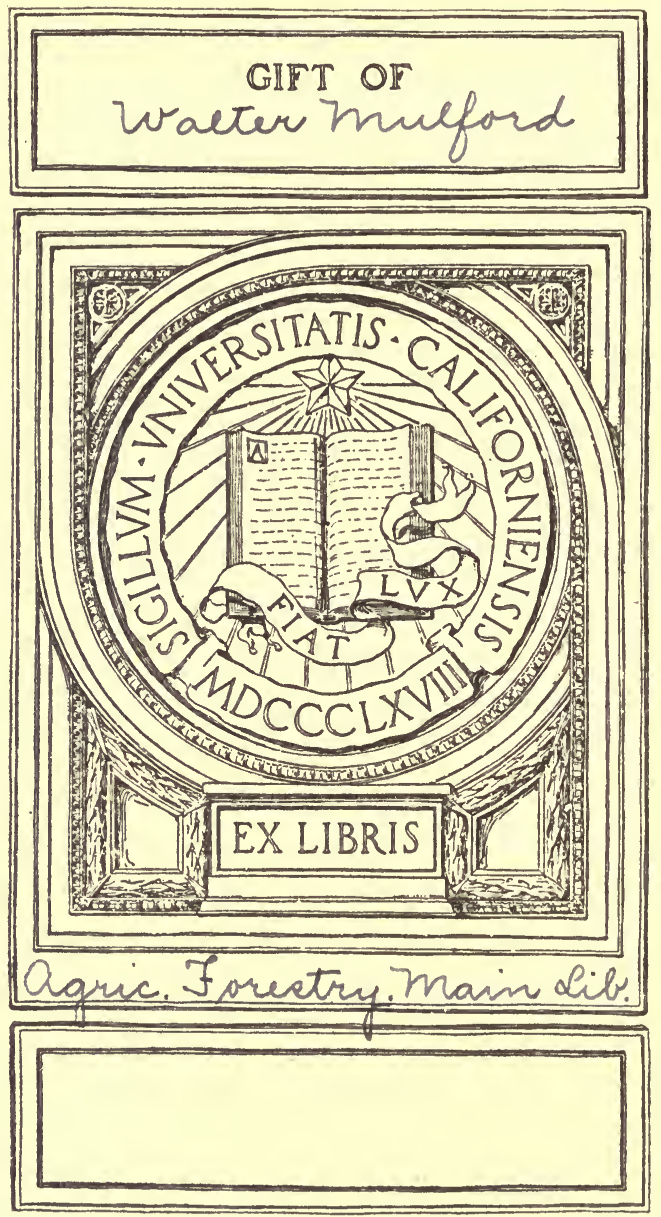




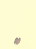





\title{
INSTRUCTIONS FOR MAKING
}

\section{IMPROVEMENT TH I N N I N GS}

\section{AND THE MANAGEMENT OF MOTH-INFESTED WOODLANDS}

\author{
BY \\ H. O. COOK, M.F., Assistant Forester \\ AND \\ P. D. KNEELAND, M.F. \\ Forester, Moth Division \\ UNDER THE DIRECTION OF \\ F. W. RANE, State Forester
}

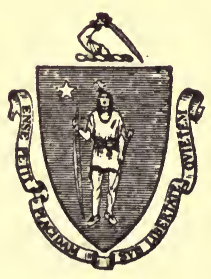

WRIGHT \& POTTER PRINTING CO., STATE PRINTERS

32 DERNE STREET :: :: :: BOSTON, MASS. 




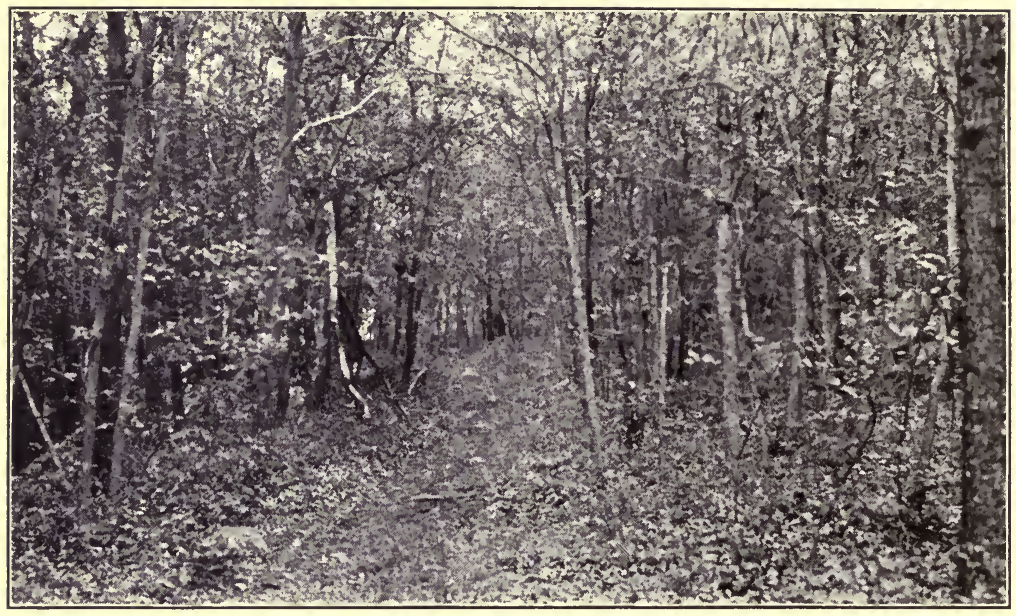

A neglected and badly moth-infested woodland. The growth bere is not large enough to pay for thinning, and contains quantities of dead trees, which condition is one of the worst to deal with. Alout all that can be done is to cut it clean and replant. There are many acres of this type and they are most dis. couraging propositions to the owners. Starvation methods may be practiced under favorable circumstances.

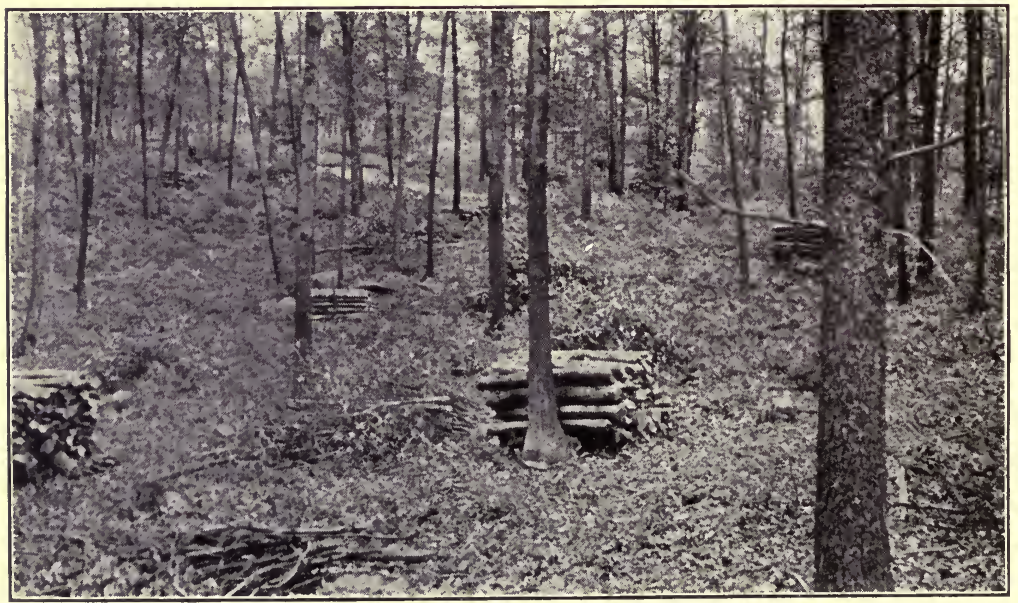

A woodland thinning to assist in controlling the gypsy moth. The favorite food trees are removed. The white pine is encouraged. A process of build. ing over the forest. A thinned forest like this can be sprayed and looked after at far less expense. The forest products removed pay for the treatment. One hundred acres on the Weld estate, Dedham. 


\section{HOW TO MAKE IMPROVEMENT THINNINGS IN MASSACHUSETTS WOODLANDS.}

\section{IMPORTANCE OF THINNING.}

By improvement thinnings and cuttings we mean the systematic removal of a portion of the trees in a growing forest, in order to benefit the portion that remains. It is the forester's method of cultivation, and it is the only practical way he has of increasing the yield and improving the quality of his crop. The methods of the arboriculturist are, except in limited cases, too costly to have a place in practical forestry.

'Those people who doubt the value of forestry practices often argue against thinnings, on the ground that nature's methods must be the best. It is no more true that nature's methods are best in the forest than in the orchard or garden. The practice of thinning in European forests for nearly one hundred years has established beyond a doubt that this work increases the amount and quality of the lumber. In 1830 the average annual growth in German forests was 20 cubic feet per acre, while in 1904 it was 65 cubic feet, - an increase of 300 per cent., which can be attributed almost entirely to the methodical thinning of their forests.

Nearly 45 per cent. of the land area of Massachusetts is covered with some form of woodland growth, which can be apportioned roughly among three main types; the pine forest, which has come up on abandoned fields and pastures; the mixed growth, composed of hard woods, usually of seedling origin; together with pine and hemlock and sprout forest. Above an altitude of 1,200 feet spruce replaces pine. A seedling tree is one which has come from a seed or nut; and by a sprout we mean one which had its origin in a sucker sent out by a stump from which a tree has been cut.

The principles of thinning apply to all kinds of forest, but it is perhaps the sprout land which chiefly needs improvement. It is the largest single type, and yet, with the exception of sprout chestnut, which is used for ties and poles, this sprout land is at present producing nothing but cord wood. Proper care might bring these cord wood stands to producing saw timber. 


\section{THEORY OF THINNING.}

In order that one may understand the principles which underlie the process of thinning, he must know something of the physiological growth of single trees, and of that collection of trees known as a forest.

Plants are made up of tissues composed of numberless small cells. These cells are largely composed of carbon derived from the carbon dioxide of the air and water. The carbon dioxide enters into the leaves through minute pores (stomata), and by the action of the sunlight on the green chlorophyll grains, the process of assimilation, which in plants answers to digestion in animals, takes place. The carbon is combined with the water and a small amount of mineral matter taken from the soil by the roots to form the growing material of the plant, while the oxygen is returned to the air. Therefore any crowding or shading which deprives the tree of these necessary agents, foliage and sunlight, checks its volume growth in proportion.

To take a simple example, let us suppose a plantation set out with seedlings 6 by 6 feet apart; then there will be 1,210 trees on an acre, and each tree will have 36 square feet in which to spread its branches. When the side branches meet we have what is called a closed stand, and a struggle commences. It is characteristic of trees to take all the room they can get; and not having any more at the sides, they seek the sunlight by growing upwards at a rapid rate. Trees even of the same species differ in their rate of growth, so that some get ahead of the others; and when they do, they spread out their side branches and so overtop their weaker neighbors. Unless these overtopped trees happen to be in the class called by foresters tolerant, i.e., shade-bearing, they will soon sicken and die. By the time our plantation is fifty years old, only 400 trees will remain of the original 1,210.

In the early life of the forest, say the first fifteen to twenty years, a sharp conflict of this kind is very useful, for it produces all tall, straight trees; in the second place, on account of the dense crowding the side branches are killed off when young, and the tree is free from knots; and in the third place, the ground is kept shaded and the moisture retained in the soil. After twenty years growth, however, these objects have been accomplished, and then the forester steps in and opens up the stand so as to allow the crowns to spread. Larger crowns mean, of course, a more rapid increase in volume growth. Furthermore, the slower-growing trees 



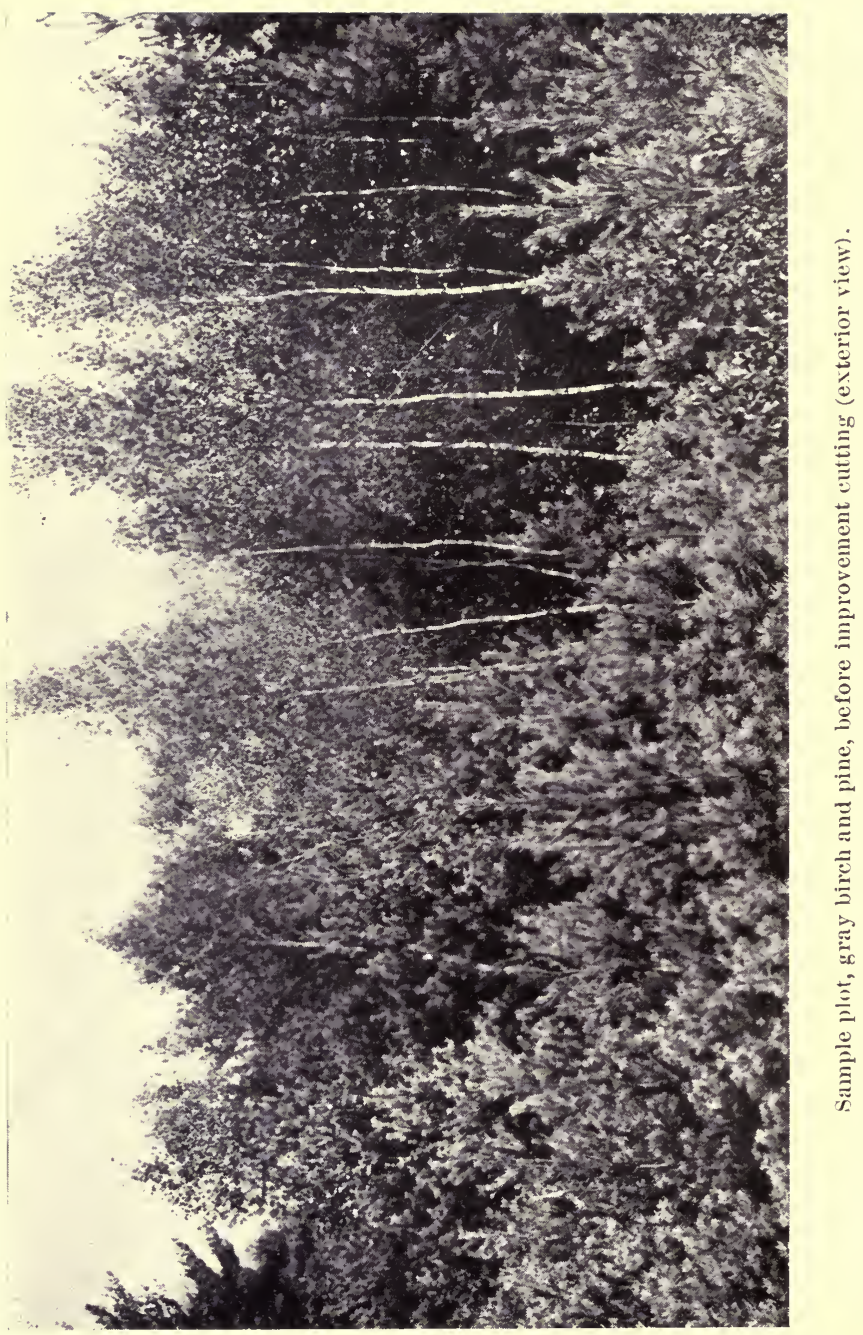


are removed while they are still alive and fit for use, and are not allowed to gradually sicken and die, an invitation to insects and diseases of the forest.

In the case of sprout land the crowding is generally more severe and the need of thinning more urgent than the plantation supposed above, for from every stump 10 to 50 suckers may spring, so that several thousands of young trees may start up on an acre.

\section{PRACTICE OF THINNING.}

WHEN TO THIN.

The conditions which exist in most parts of this country do not permit us to thin as early or as often as is desirable. The market for small-sized wood is uncertain, and we must be satisfied with a less intensive cultivation of our forests than our European friends enjoy.

A safe rule to follow is to thin a stand as soon as the material to be removed has reached such a size that its sale will pay the cost of the removal, and as soon again as the material to be removed has accumulated in sufficient quantities to pay the expense involved. The profit is to be found in the improved growth of the stand. When the wood lot owner is a farmer, or has farm help during the winter months, when they might be idle much of the time, the net cost of the work may be held quite low.

A less commercial and a more scientific rule would state that a thinning should be made as soon as the trees have attained their maximum rate of height growth, and the lower limbs are well pruned off. In practice this would mean a moderate thinning when the stand is from twenty to thirty years old, and a heavier one ten to fifteen years later. If the rate of growth of our native trees and their response to treatment were better known, we could afford to thin at some net expense, being able to calculate what the profit would be; but unfortunately American foresters have not had time to gather the necessary data on this subject, and until we do, the rule of letting the material pay the expense is the best to follow.

\section{What to Thin.}

The extent to which a closed stand may be opened up depends on several circumstances. Species which are called "tolerant," because they stand the shade well, should be kept quite thick, for they cling tenaciously to their side limbs. Hemlock and beech are extreme examples of "tolerant" trees. A forest on a dry, 
sandy soil or on a hilltop should not be thinned as heavily as one on low, moist ground, because under such circumstances the soil must be kept shaded to retain the scanty supply of moisture. The age of the trees and the kind of timber desired have an influence on the decision of what to take. For instance, if the owner of a chestnut sprout stand wishes it to yield poles rather than ties or lumber he should thin it lightly.

The simplest problem of thinning is in a wood lot consisting of but one species. We first divide the trees into four classes: dominant, intermediate, suppressed and dead. Dominant trees have large, full crowns, well up in the light. Intermediate trees receive light from above, but are somewhat crowded at the sides, some more than others. Suppressed trees are those which have been wholly overtopped by their more vigorous neighbors, and are slowly dying. A moderate thinning would consist in the removal of the intermediate trees, which are closely pressed by their neighbors, and all the suppressed trees if they will make a marketable product. Dead trees do no injury to the growing crop, and are only removed to improve the appearance of the woods, or as a precaution against fires, insects and disease.

When the wood lot contains a number of species the problem becomes more complicated, for we have the relative value of species as another factor which we must consider. The relative worth of different species depends in part on their value in the market; in part on the owner's plans as to the final disposition of the wood lot; and in part on their adaptability to the soil in which they are growing.

The hardwoods of the eastern part of the United States are divided into two types: the northern and the southern. Generally speaking, the order of preference in the northern hardwoods would be rock maple, paper birch, yellow birch and beech. Among the southern hardwoods the names might be arranged as follows: chestnut, white ash, red oak, hickory, white oak and soft maple. Gray birch, poplar and wild cherry are usually classed as forest weeds, and are taken out. Where these latter three species are growing by themselves, and are not interfering with other and better trees, they can of course be left; but they are not worth any improvement work.

Where white pine is mixed with deciduous trees it is usually favored at their expense; and spruce in the higher altitudes should be similarly benefited. Pitch pine, however, is in a class below 



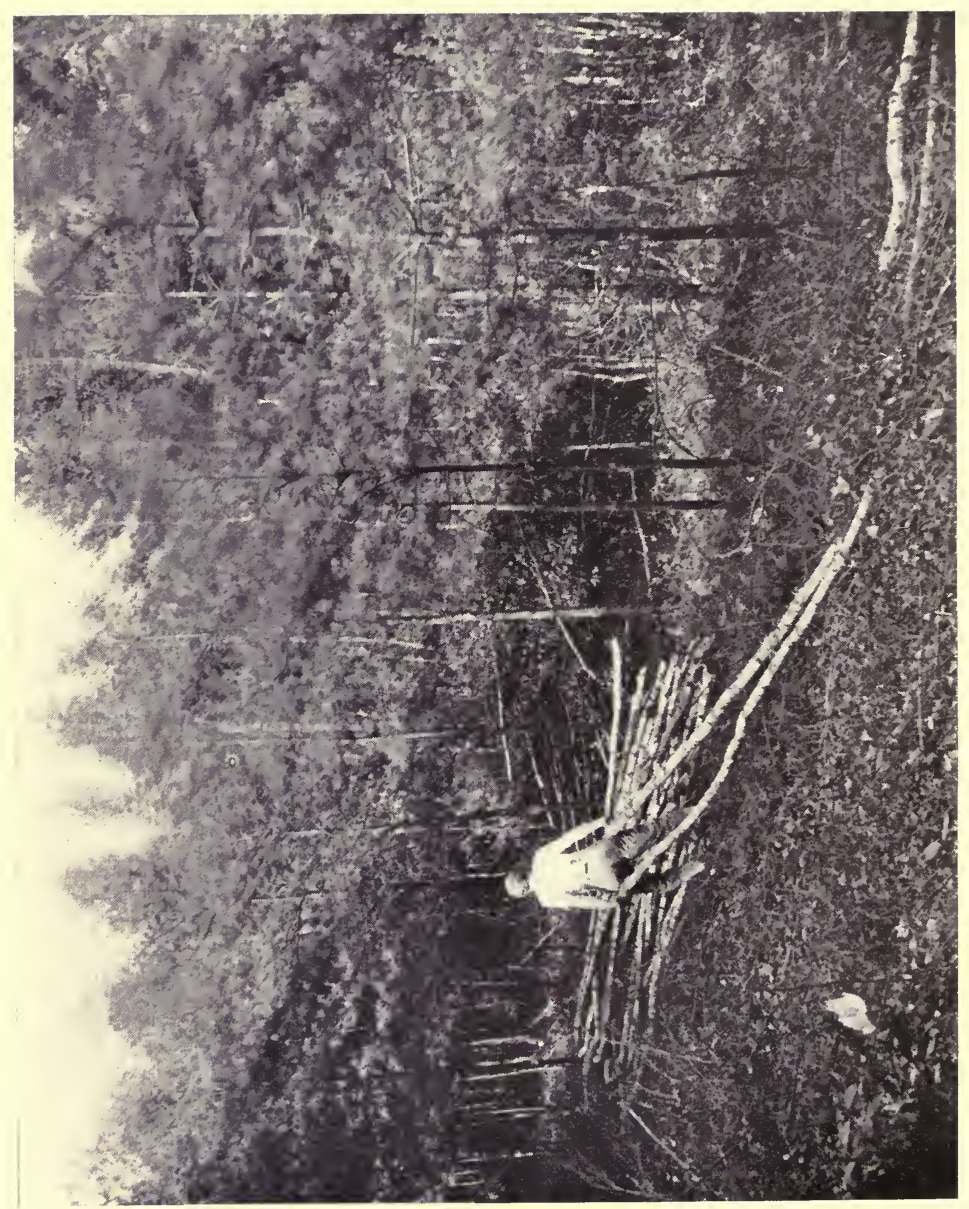

 
the better hardwoods; and there is no call to favor hemlock, because it is very "tolerant."

After the trees have been classified and the order of preference by species determined upon, a third consideration must enter into our calculations. Defects, such as decayed trunks, fire scars or extreme crooks, are a sufficient reason for the removal of a tree, so that it is not impossible to have a wood lot in which the dominant trees, being in poor condition or of a valueless species, would be removed. Such a cutting could, however, scarcely be called a thinning, but would rather partake of the nature of an improvement cutting.

One can readily understand that the man who is put in charge of a thinning operation must have sound judgment, and be well instructed in the principles of the work. Where possible, it is well to have a trained forester mark the trees to be cut. It is better to be conservative rather than radical in the selecting of the trees to be removed, as a thinning which is too light can be easily remedied, but one which is too heavy will take years to mend. A mere cleaning up of the underbrush and a few suppressed trees is not a thinning, however.

In practice it is customary to blaze the trees to be cut, and often they are blazed twice, once about 4 feet from the ground, and once low down on the stump. Unless one has great confidence in his man, it is not wise to let the chopping out at so much a cord, because as a rule in a thinning operation we take only the smaller and poorer trees, so that the chopper is under a great temptation to increase his pile by taking some of those intended to be left, and it is difficult to detect the fraud.

\section{Thinning Chestrut Woodlands.}

Very frequently it becomes advisable for the wood lot owner to carry on thinning operations in stands of pure chestnut or in mixed hardwood growth, with chestnut forming a large part of the mixture.

This is especially the case in stands of from twenty-five to forty years of age, where the competition has been so great that the trees have grown very slowly in diameter. Height growth has been secured at the expense of growth in diameter.

Chestnut, because of its great sprouting capacity, generally grows up in a dense stand, the number of sprouts from one stump 
ranging from 3 to $\%$, sometimes even more. This makes for height growth.

A moderate thinning would remove only the dead, suppressed and poorer intermediate trees. This would not stimulate diameter growth very much, and it is this diameter growth which is desired in the chestnut stands of the ages mentioned above.

The advent of the chestnut blight, and the possibility of the destruction of the chestnut by this fungous disease within a comparative short length of time, makes it imperative that the stands of chestnut should be brought up to merchantable size as fast as possible.

A heavy thinning, which would include the trees removed in the moderate thinning, with the addition of some codominant trees, would result in increased rate of growth.

A damage cutting should be made at the same time as the thinning and all diseased trees removed. This should be repeated every year or two if possible.

\section{Explanation of Diagrajis.}

We have endeavored to represent in Diagram No. 1 a section of a typical sprout chestnut stand, 50 feet in length and 20 -feet in width. The trees of the dominant class are marked A; the intermediate class, B; and the suppressed trees, D. The small maples, although apparently suppressed, are not so; but, being very tolerant of shade, they have come up under the shadow of the chestnuts, and form a sort of second cover. The trees removed in thinning include five suppressed, two intermediate and one dominant. The dominant chestnut was removed primarily because of its poor, crooked bole; and secondarily because there was a good red oak and a chestnut ready to grow into the vacated space. The maples were not cut because they were so small that they could not interfere with the larger trees, and they help to keep the ground shaded until the broken cover is re-established. Diagram No. 2 represents the stand as it appeared after the thinning. 


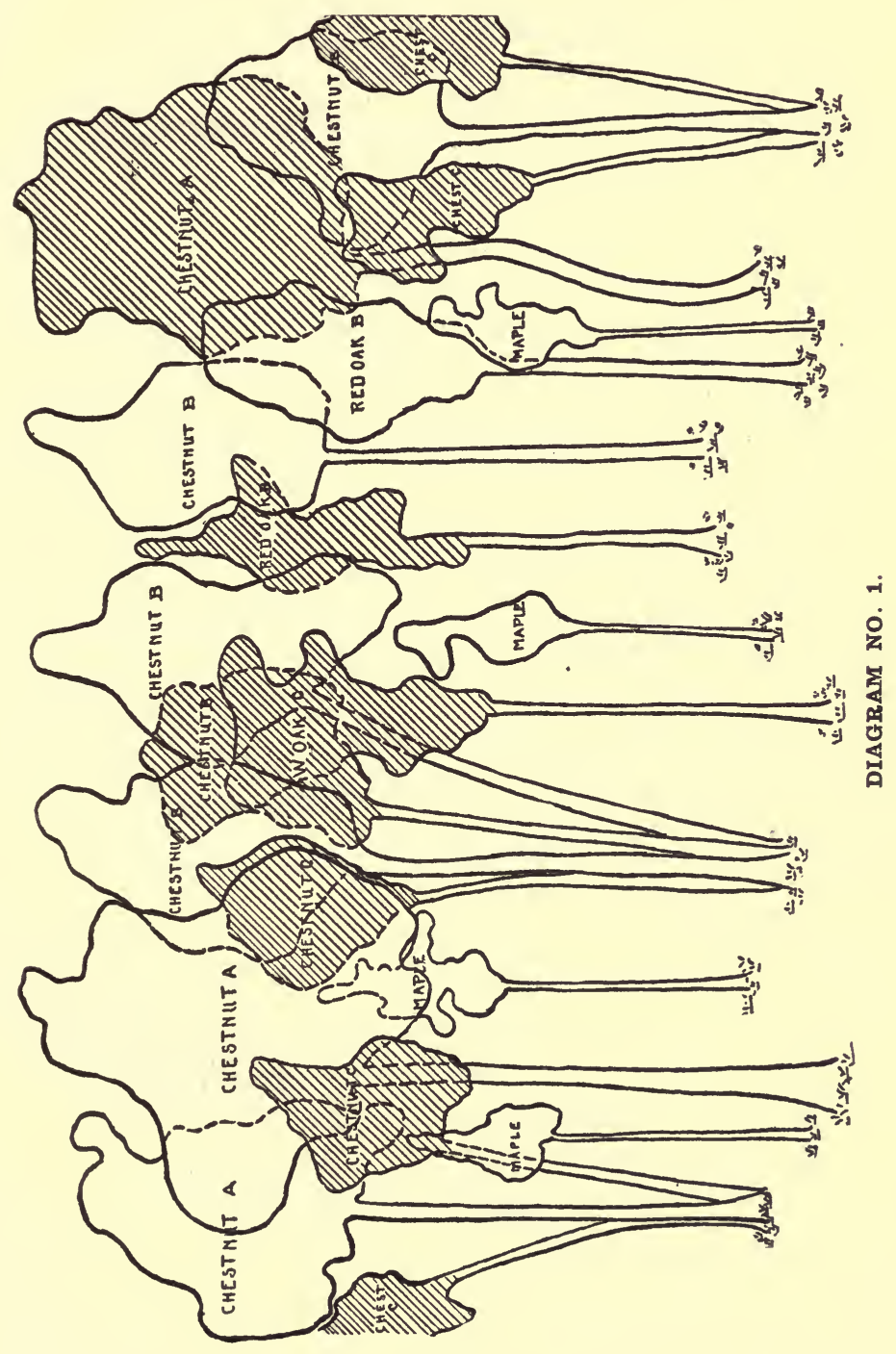




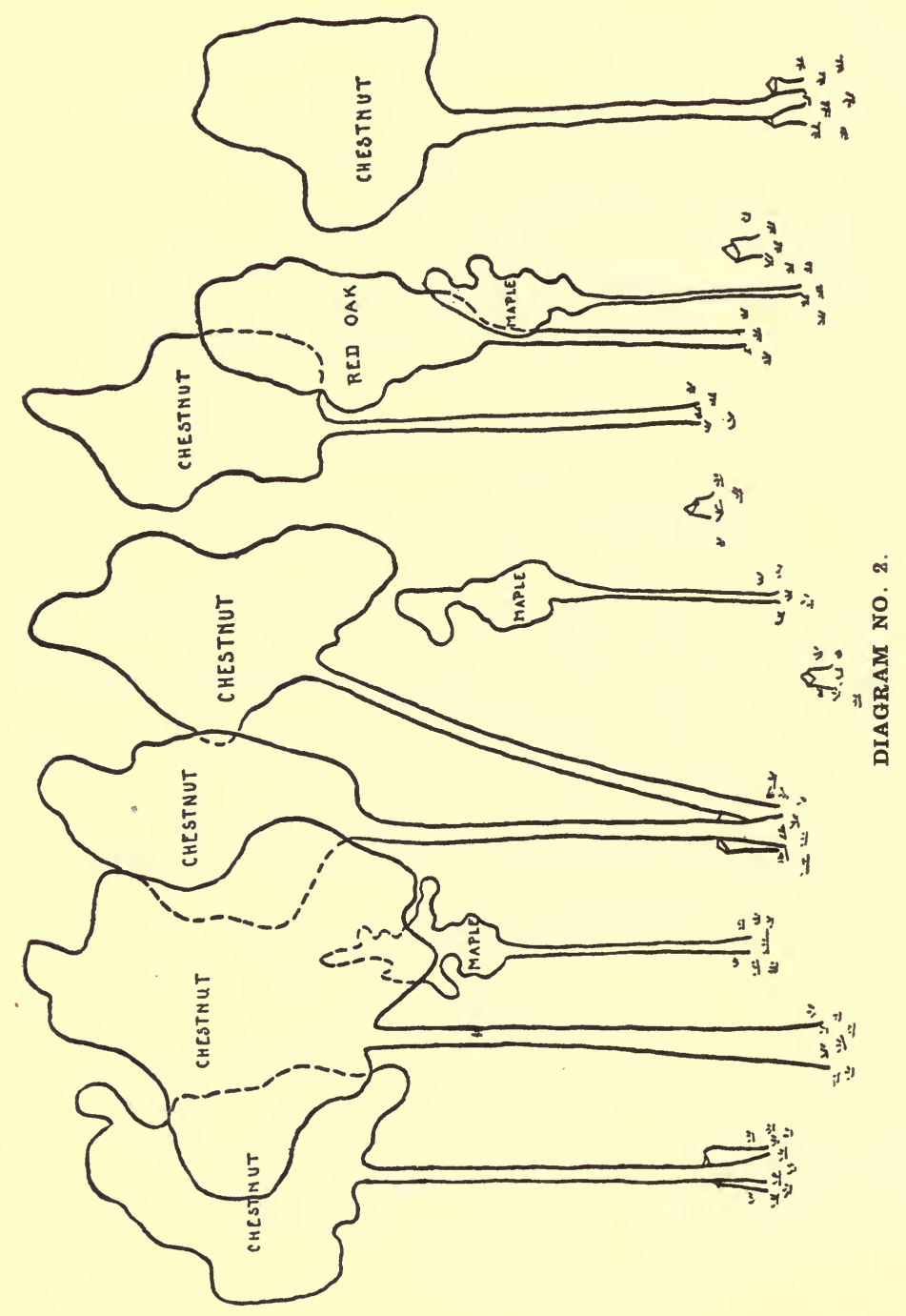




\section{RESULTS OF THINNING.}

We said in the section on the "Theory of Thinning" that the more light and air a tree receives the more rapidly it grows in diameter; so that a thinning, by opening up the stand and allowing the crowns of the remaining trees to enlarge, stimulates the volume growth of the stand. There are fewer trees in the stand, but larger and better ones. This may not be considered important until we realize how much more valuable a tree of large diameter is than a small one. For example, the average white pine, 10 inches in diameter breast high, and 60 feet in height, contains 95 feet of round-edge lumber; whereas a pine of the same height, 15 inches in diameter, contains 195 board feet of lumber; that is, with a 50 per cent. gain in diameter there is an increase of 100 per cent. in the product. This is not the whole story, because with the increase in the size of the tree the boards are wider and have less knots, yielding a higher price; so that the gain in money value is even greater than the increase in volume. An average chestnut tree 10 inches in diameter will produce 2 ties and .03 cords of firewood. Supposing a railroad tie to be worth $50 \mathrm{cents}$, the tree may be said to be worth about $\$ 1$. A 15 -inch chestnut will yield 5 ties and .06 cords of wood, worth about $\$ 2.50$, or an increase in money value of 150 per cent. In the case of sprout oaks and other sprout hardwoods, thinnings made at the right time may result in converting what would otherwise be nothing but a cord wood lot into one of saw-timber size.

If, as a result of thinning, the trees become larger in a given space of time, conversely they will attain any suitable size in a shorter space of time than without a thinning. The experiments of European foresters have shown that the rotation of the timber crop can be shortened by judicious thinnings from 10 to 20 per cent.

In the course of this work many unsightly and diseased trees are removed, and this fact tends to make the woodland more attractive to the eye. Where forest land is used for park purposes as well as for timber production, a moderate thinning is highly recommended. It should, however, be conducted under careful supervision, as the tendency is often towards a "sand-papering" treatment of the woods, to which many people who appreciate primitiveness in nature object; and they wrongfully believe this effect to be a necessary result of forestry work. 


\section{IS THINNING PRACTICABLE?}

There are many owners of forest property who, although they do not doubt that a thinning will benefit their woods, say that the cost of the work is prohibitive. Of course there are many places in this State so remote from a market that the product will not even pay the charge for labor; but the trouble with most of these people is that they want to get back their wages, a fair stumpage, and often an additional profit from work meant for improvement only. It is an especially valuable line of work for the landowner who is obliged to keep men and horses through the winter months, with little for them to do. Such a man makes something out of the thinning work, no matter if the actual returns are small.

In the sprout hardwood stands, from 3 to 8 cords will be found to be the usual product of thinnings, depending on the age and density of the stand. In the seedling hardwoods and mixed stands the density is so variable as to make any definite statement in regard to the probable product of thinnings impossible. As a rule, about one-third of the trees, and from one-fifth to one-quarter of the total volume in the wood lot, are taken out in this work.

Two years ago this office published a small pamphlet containing data on the white pine. Part of this booklet was given over to yield tables. A pine yield table is one which shows the volume of well-stocked pine stands at different ages, which in this case ranged from twenty-five to fifty-five years. These tables were made by measuring the trees on many sample plots of all ages, and averaging the results. When these sample plots were calipered, those trees which would be removed if the stand was thinned were noted separately. From this data a table of the yield from pine thinnings was made and published at that time. We print it again in this pamphlet, on account of its connection with the subject.

\section{YIELd FROM ThinNings.}

Trees under 5 inches, from report of the New Hampshire Forestry Commission, 1906.

\begin{tabular}{|c|c|c|c|c|c|c|c|c|c|c|c|}
\hline \multirow{2}{*}{\multicolumn{2}{|c|}{ AGE }} & \multirow{2}{*}{\multicolumn{2}{|c|}{ (YEARS). }} & & \multicolumn{4}{|c|}{ Trees over 5 Inches in Diameter. } & \multicolumn{3}{|c|}{$\begin{array}{l}\text { Trees UNDER } 5 \text { INches iN } \\
\text { DiaMeTER. }\end{array}$} \\
\hline & & & & & $\begin{array}{c}\text { Board } \\
\text { Feet. }\end{array}$ & $\begin{array}{c}\text { Value at } \\
\$ 16 \\
\text { per M. }\end{array}$ & $\begin{array}{c}\text { Stump- } \\
\text { age } \\
\text { at } \$ 6 \text {. }\end{array}$ & $\begin{array}{l}\text { Cubic } \\
\text { Feet. }\end{array}$ & Cords. & $\begin{array}{c}\text { Value at } \\
\$ 3 \text { per } \\
\text { Cord. }\end{array}$ & $\begin{array}{l}\text { Cubic } \\
\text { Feet. }\end{array}$ \\
\hline $\begin{array}{l}25, \\
30, \\
35, \\
40, \\
45, \\
50, \\
55,\end{array}$ & . & $\begin{array}{l}\ddots \\
: \\
: \\
:\end{array}$ & $\dot{.}$ & - & $\begin{array}{l}1,400 \\
3,700 \\
4,950 \\
6,000 \\
6,800 \\
7,400 \\
7,900\end{array}$ & $\begin{array}{rl}\$ 22 & 40 \\
59 & 20 \\
79 & 20 \\
96 & 00 \\
108 & 80 \\
118 & 40 \\
126 & 40\end{array}$ & $\begin{array}{ll}\$ 8 & 40 \\
22 & 20 \\
29 & 70 \\
36 & 00 \\
40 & 80 \\
44 & 40 \\
49 & 40\end{array}$ & $\begin{array}{r}280 \\
720 \\
850 \\
1,030 \\
1,140 \\
1,240 \\
1,310\end{array}$ & $\begin{array}{l}71 / 2 \\
6 \\
41 / 2 \\
3 \\
11 / 2 \\
- \\
-\end{array}$ & $\begin{array}{rl}\$ 22 & 50 \\
18 & 00 \\
13 & 50 \\
9 & 00 \\
4 & 50 \\
- & -\end{array}$ & $\begin{array}{r}750 \\
600 \\
450 \\
300 \\
150 \\
- \\
-\end{array}$ \\
\hline
\end{tabular}




\section{MISCELLANEOUS CUTTINGS.}

There are many kinds of cuttings which one can make to improve woodland which cannot strictly be called thinnings because their primary object is not to open up the crown cover in order to stimulate the growth of the trees. It is not always possible to draw a hard-and-fast line between such improvement cuttings and thinnings because one may partake of the nature of the other, and the two may be carried out at the same time. Such cuttings can best be suggested by a few examples.

We will suppose that an insect pest which attacks some particular species of tree - for instance, maples - is more or less prevalent in a region. As a matter of protection, the owner of mixed woodland might go through it and take out all the maples so as not to attract the insects to his land. The removal of hardwoods from a pine stand as a precaution in fighting gypsy moths is another protection cutting, which we have described elsewhere in this bulletin.

One often finds among the woods large, spreading old trees, more or less decayed and of little value for timber. It is good forest policy to cut such trees down, and to allow the large amount of ground space which they occupy to come up to a new growth of more value.

In old, abandoned pastures we often see young pines coming up underneath a stand of gray birches. While the pine seedlings are very young, let us say not more than four or five years old, the birches protect them from the hot sun and wind, and act in the rôle of nurse trees. But as the pines increase in size they need the sunlight; and, further, the branches of the birches, as they sway in the wind, cut the tender leading shoot of the pine, killing it and causing the tree to be stunted and crooked. In such cases the birches should be removed; but if they are too small to make cord wood, or if the young pines are scattered, it is only necessary to remove the trees immediately surrounding the pines. If done in this manner, one man can easily cover an acre or two a day.

If diseased or decaying trees are removed from a stand with no special reference to the principles of thinning, the operation is an improvement cutting and not a thinning. 


\section{THINNINGS IN GYPSY AND BROWN-TAIL MOTH WORK.}

Thinnings are a logical development in the fight against the gypsy and brown-tail moths. However, thinnings as made in this work differ considerably from the improvement thinnings previously mentioned, and perhaps some other term should be used to describe them. They vary all the way from what practically amounts to clear cutting to merely the chopping out of underbrush and dead trees.

\section{Methods of Moth Control.}

Some account of the habits of the gypsy and brown-tail moths and the methods used in their control may help in explaining the purposes and possibilities of moth thinnings. The present means of fighting the moths may be classified under three heads, - direct entomological methods, indirect entomological methods and forestry methods. The direct entomological methods seek the destruction of the moths in one of their various forms by human agency, as in spraying or creosoting. The indirect methods seek the propagation of parasites or disease which will destroy the moths. The forestry methods seek the eradication of tree growth which is favorable to the moths, and, conversely, the encouragement of growth unfavorable to their development.

It has been found, from our own and from European observations and experiments, that although it will eat practically all kinds of vegetation, the gypsy moth thrives only on a limited number of species of trees. 'These trees, which are the oaks (especially the white oak), willow, cherry and fruit trees, and probably the gray birch, may be called "non-resistant" trees. The brown-tail moth is virtually the same, except that it will not eat coniferous growth (pines, etc.) at all. Unless a large proportion of their food consists of the leaves of these "non-resistant" trees, under ordinary conditions both gypsies and brown-tails will soon either pass on to a more favorable feeding ground or die. Therefore forestry methods rather than attempting to destroy the moths themselves would destroy their food. If we grow forests of resistant species, as conifers, maple, ash, chestnut, etc., the moths will cease to be destructive. 


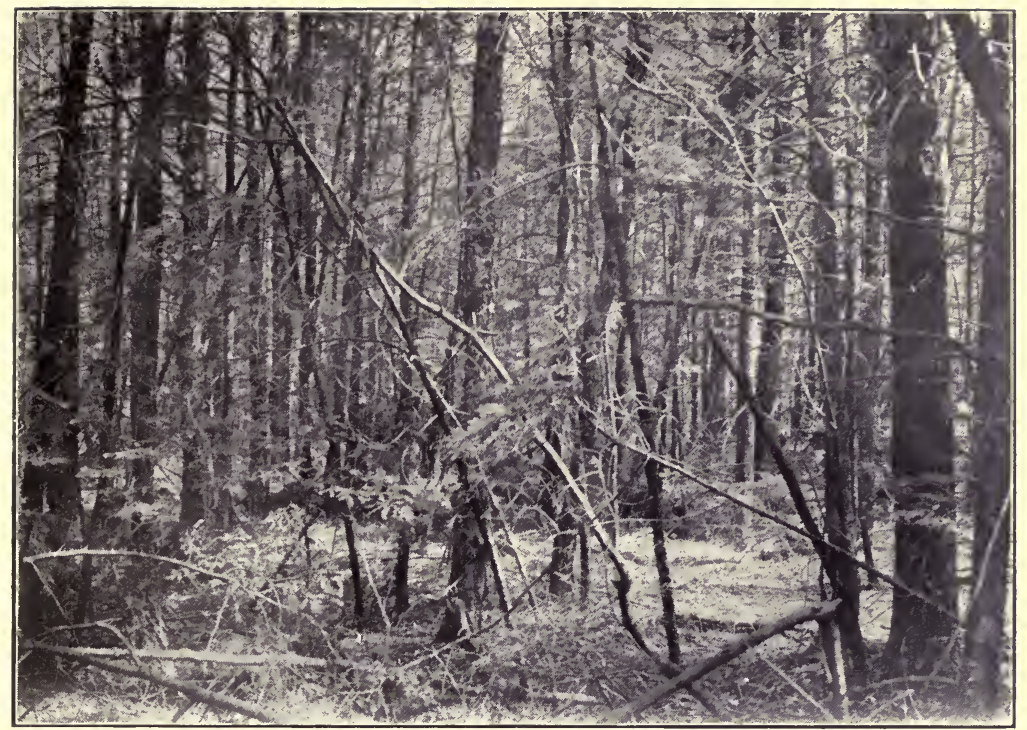

Before thinning, at Manchester-by-the-Sea. Imagine the difficulty in treating this woodland for gypsy moths as it is.

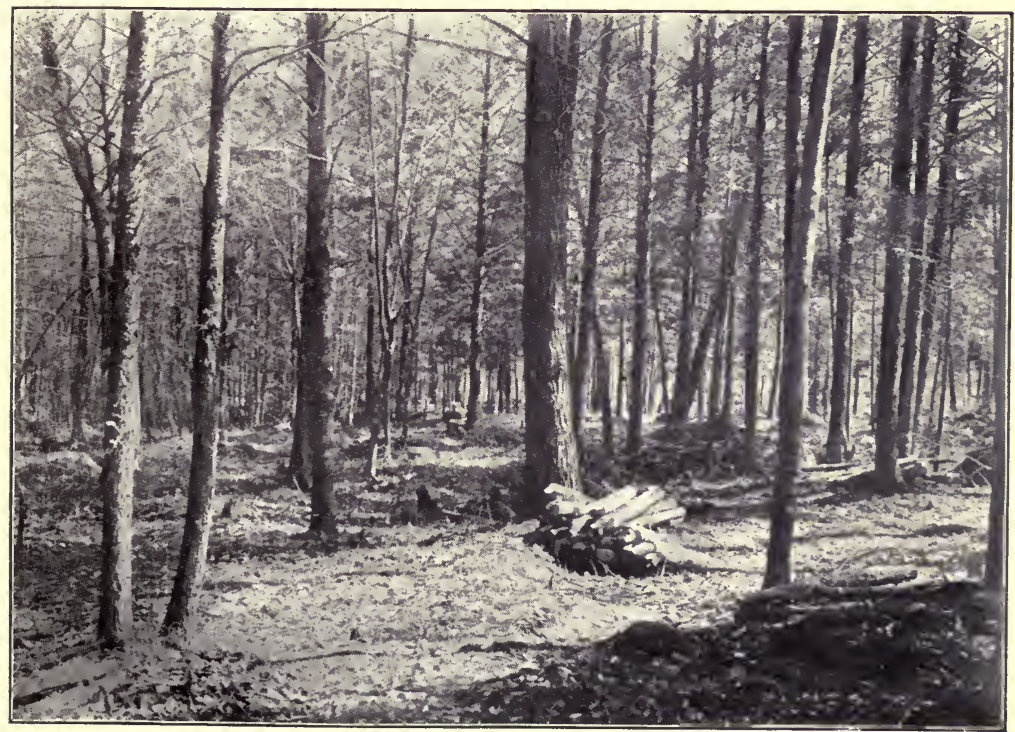

After thinning, at Manchester-by-the-Sea. Not only are the conditions better for combating moths, but the improved forestry conditions are erident. 

The forestry methods of control consist of what we here term moth thinnings. The moths themselves carry on these thinnings in a crude way if left to ravage undisturbed. They will kill off most of the "non-resistant" trees, together with many " resistant" ones, it is true; but after many years, if undisturbed, the forest will grow up almost wholly "resistant." Moth thinnings will prevent the large waste which this natural method would entail, and also will hasten the regeneration of the forest and save many "resistant" trees which would not be killed unless mixed with the "non-resistant" species. Thus these thinnings, like other kinds of thinnings, are for the purpose of saving and encouraging the growth of the forest as a whole by sacrificing some of its unnecessary or dangerous individuals.

\section{KINDS OF THINNINGS.}

Moth thinnings may be classified under four different heads which are more or less distinct.

1. Cuttings made solely for the Purpose of aiding in Direct Methods of Moth Control. - These are not real thinnings. They usually consist of merely taking out the underbrush and a few dead or undesirable trees. They have been carried on for years in practically all park and ornamental woodland where large sums of money were to be spent in spraying the trees or painting the eggclusters. They are based on the principle that cuttings of this character will greatly lessen the cost and increase the effectiveness of the other work.

2. Cuttings which are made for the Purpose of leaving the Woodland wholly "Resistant." - Not over 5 to 10 per cent. of "nonresistant" trees are left after a thinning of this sort; the brush may or may not be cut, according to its character, and the expectation is that no further measures of moth control will be necessary. These are moth thinnings of the extreme type. In stands which have a good percentage of resistant growth they are real thinnings and leave a fair forest cover. In stands almost wholly non-resistant they practically amount to clear cutting, and should always be followed by reforestation.

3. Thinnings which are a Compromise between the Two Preceding Kinds. - In the cutting all possible non-resistant trees are removed, but not enough to seriously break the forest cover, and it is expected that further measures of moth control, as spraying, will be utilized when necessary. One purpose of this type of cutting 
is to enable the owner to maintain a forest cover at the least possible expense, with no unnecessary trees to take care of, and with the largest possible proportion of resistant trees. The real purpose of these thinnings should be to make it the first step in a gradual elimination of all non-resistant trees, and the remaking of the forest into one of a resistant character without too great a disturbance of the forest conditions during the process. Natural reproduction or underplanting of desirable species should follow the cutting.

4. Damage Cuttings. - 'To a greater or lesser extent in all woodland where the moths have been present for a number of years there are moth-damaged trees which have to be removed when a.thinning is made. However, under this heading it is intended to include only cuttings made for the main purpose of marketing the dead and damaged trees before they become too much decayed to be merchantable. Of course this sort of a cutting has no effect in controlling the moths. The wood cut from dead trees is not usually as valuable as that cut from live ones, and also it costs more to cut it; so damage cuttings are only profitable in better quality growth near a good market. Resistant thinnings should be made where possible before serious infestation, to prevent the necessity of damage cuttings.

Advantages and Disadvantages of Thinnings as a Method of Moth Control.

The great advantage of thinning is in its small cost. The direct methods of moth control are a net expense and are liable to have to be repeated year after year. In most woodland the annual cost of spraying or of a thorough creosoting is greater than the value of the wood which that woodland will produce in a year. Therefore it is cheaper for the owner, unless the area has a considerable value other than for the wood it grows, to cut down all his trees and sell them than to try direct methods of control. This fact is well known, and is the reason why in recent years little attempt has been made to stop the moths in woodland unless it was mainly used for park or pleasure purposes, or in case of a light infestation, to keep it from spreading.

Moth thinnings will pay for themselves, or come very near doing so, as will be seen from figures of actual operations which are given later. The product in cord wood, ties, piles, logs, etc., will, in almost every growth which is at least fair, pay for the work done, and in many cases will yield a profit. 
Moth thinnings in many types of woodland offer a permanent solution of the moth problem; they do not call for a heavy annual expenditure.

In all woodland, thinnings will aid and lessen the cost of other methods of control, even if not in themselves completely solving the problem. A thinned area can be sprayed for a fraction of the cost of the unthinned, and the work is much more effective. The same is true of creosoting, clipping nests, etc.

In wild woodlands the chief value of which is for the wood they produce, thinning with the aid of parasites and diseases seems to offer the only reasonable solution of the problem.

However, it must be remembered that moth thinnings are not a cure-all for every phase of the moth problem. It is desirable, and always will be, to grow " non-resistant" species for shade trees and in park, ornamental and protection woodland. Here the other methods must be continued.

There is a great class of woodland which is so poor that no possible cutting will pay for itself. This includes young sprouts, gray birch growth and areas which contain a large amount of brush, as scrub oak, hawthorn, briars, etc. Moth thinnings are so expensive in these lands that they can hardly be advisable. However, some people have cleaned them off and replanted to pine. Where there is considerable young pine mixed with the other growth on these areas a thinning will pay in future returns from the pine, even though the wood removed will not cover the first cost.

\section{Results of Moth Thinnings.}

The result of moth thinnings and of natural selection in the case of badly infested woodland will be the elimination of a large part of the oak from our forest growth. This will prove to be a blessing rather than a disaster if pine is substituted. Most of the sprout oak in the moth-infested territory is occupying natural pine land. The soil is poor and unsuited to the best development of oak, but is excellent for pine. It is thought that originally the land was almost wholly covered with pine. The pine has the advantages of being more valuable, more rapid growing, and generally more satisfactory and productive than the oak in this region. Oak can be left on the richer soils and moister slopes, where it may be able to withstand the ravages of the moths. Generally the oak must be relegated to the position of unimportance which it occupies in European forestry, and the white oak, the poorest of ali in this 
region, will be almost exterminated. Of the other trees affected, the cherry and gray birch are weed trees, and so of no importance, and the willow is rather uncommon and quite capable of withstanding repeated moth attacks.

\section{HOW TO THIN.}

The types of forest growth in the cut-over lands of Massachusetts are so many and the conditions are so varied that no hard-and-fast rules in thinning can be laid down. Outside of forest conditions the wishes and purposes of the owner of a specific tract must be one of the main factors to determine the method of its treatment.

If a stand is almost purely non-resistant, as an oak growth, it is for the owner to decide whether he wants the stand clear cut at once and replanted with pine, or whether he wants to gradually thin out the area, and underplant, keeping all the while some sort of forest cover. The first method is the cheaper, but the woods are gone for a number of years until the pine grows up. If the second method is chosen, practically all white oaks should be cut out anyway, as they are by far the most undesirable trees from the moth standpoint. Of the other species of oaks only those in poor condition, of poor form, or the suppressed, overtopped and intermediate should be removed. One or two of each bunch of sprouts can usually be cut down. An intermediate tree of a resistant species, as pine or maple, should be left, and the oak which is crowding it out removed.

Where a hardwood stand of good density is to be underplanted, probably 60 per cent. numerically, and from 30 to 50 per cent. in volume, should be removed. Where there is considerable natural pine reproduction under the hardwood, or where it is possible to gain it, not all shade should be taken away, but a heavy thinning should be made. Experience has shown us that, where there is only the choice between leaving the young pine without protecting cover, or leaving white oak as that cover, it is better to remove the white oak if the moth infestation is serious.

There is one combination method of treatment in nearly pure oak stands where the owner does not wish to lose the wooded effect and yet does not want to go to the expense of taking care of the whole area.

By this method a thinned strip, which can be sprayed easily, is left along the edge, on the roads or bordering fields, and back of this strip the growth is cut clean and the land replanted. 


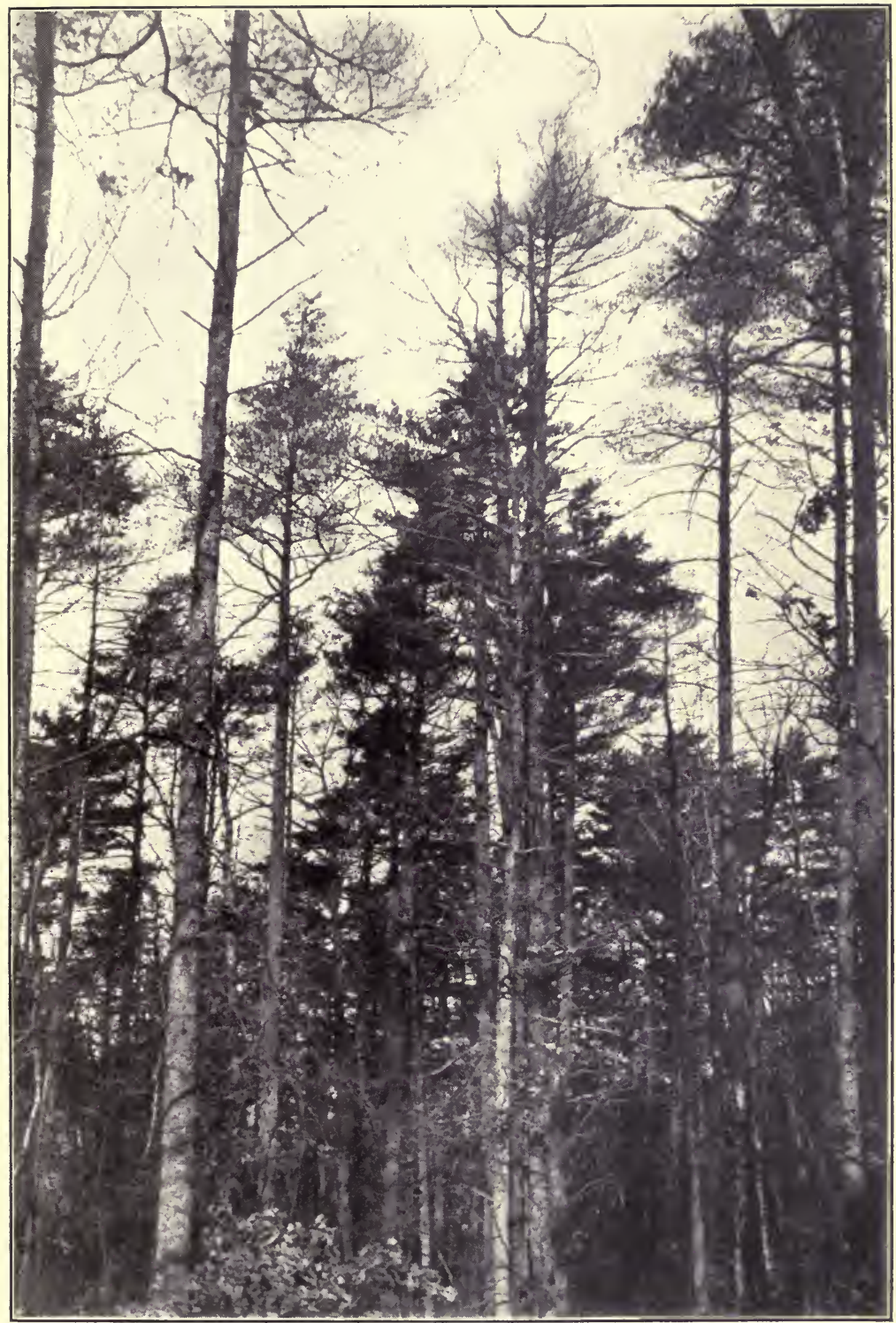

A splendid stand of large white pine with a relatively small mixture of hardwoods on the fine Rodman estate in Dedham. The pine tops show the ravages of the gypsy moth. A number of the large pines are past redemption. This whole estate is being thinned out at the present time. The hardwoods are being taken out, together with the dead pines. Had the hardwood been remored early all of the pimes could have been saved. 

In stands 50 per cent. or more of moth-resistant character practically all non-resistant trees should be removed. No white oaks, and not more than 10 per cent. of other oaks, should be left unless the owner is prepared to use other methods of moth control.

In stands which contain not over 10 to 20 per cent. oak, and the rest pine, a thinning out of all oak is especially important. It has been uniformly observed that in such stands the damage to the pine is greatest. All oak undergrowth should be removed also.

In pure or nearly pure gray birch a thinning is unprofitable and unadvisable unless the birch is large enough and the market good enough to make a clear cutting pay for itself. In stands where there is a large amount of young pine mixed with the gray birch a cutting out of all birch would seem advisable, even if made at a small present financial loss.

\section{Brush Disposal.}

The disposal of the brush and slashings is a large problem in connection with this work. The following are several general rules which have been formulated in the work this department has undertaken and supervised:-

\section{Cutting of Brush and Undergrowth.}

1. The cutting of brush is a net expense, and where financial considerations enter largely as little as possible should be done.

2. In park or ornamental woodland, or where spraying or creosoting are to follow the cutting, it is usually advisable to cut practically all the underbrush. Care should be taken, however, not to cut valuable young reproduction, as pine, maple, ash, etc., or valuable flowering shrubs, as flowering dogwood, Vibernum lantanoides, laurel, etc.

3. In ordinary woodland only "non-resistant" brush and reproduction should be cut, such as scrub oak, oak, birch, shadbush and witch-hazel.

\section{Burning of Brush and Slashing.}

1. In park or ornamental woodland; where planting is to follow the cutting; where other measures of moth control are to follow the cutting; where there is any æsthetic value to the woodland; and where the fire danger is considerable, all brush and slashing should be burned.

2. Along roads, rights of way and boundary lines the brush should be burned. 
3. Hardwood brush is not as dangerous as softwood brush, and where left it should be scattered. Brush is sometimes an aid to natural reproduction, but whether it is burned or not is usually a financial consideration with the owner. Except in the above-named cases we do not advise its being burned when the expense would be a burden.

4. Brush should be burned in the winter or spring or on rainy days.

5. Except where it is rery thick it is usually cheaper and better to pile the brush first and burn afterwards than to pile and burn at the same time.

The cost of brush disposal will be discussed later.

\section{USES AND MARKETS FOR WOOD.}

The products of these thinnings are depended on to meet completely or in a large measure the costs of the work. Therefore it is essential that the wood cut should be utilized in the best possible manner and sold to the best advantage. An enumeration of the various products obtainable and a discussion of their possibilities for profit follow: -

1. Cord Wood. - Cord wood is usually the chief product of the thinnings. It is universally cut into 4 -foot lengths in the woods and is used for fuel. It might be graded into two or possibly three grades, and also its value varies somewhat with species. The best grade is cleft wood. It is usual to split any stick over 5 inches in diameter. Wood below that size is called round, or, if very small ( 2 to 3 inches), trash wood. A small percentage - usually not over 10 per cent. - of round or trash wood may be included with cleft wood and sold as such. If there is a larger percentage than that of round wood it is a poorer grade and as high a price cannot be obtained. Trash wood is very difficult of sale, and most dealers refuse to buy any, but a certain amount can be sold locally in many places at a low price. Oak wood almost all over the State is considered the best kind, although in some places maple is more in demand. Birch is usually of less value, although near cities for fireplace use good cleft birch will often obtain a better price than oak. Birch, not split, will rot if left out in the open orer summer. Oak needs a year of seasoning before sale in most places.

In all cities of the State there is a good although limited demand for cord wood. The rural districts consume more proportionally than the cities. There are a number of dealers constantly in the 
market for wood in large quantities. In many places the owner can obtain a better price by himself selling the wood to the consumer, but to do so he must have the facilities to haul and deliver it. A large amount of wood, often of the poorer grades, is consumed by the brick yards and charcoal kilns.

'The value of the wood depends not only on its quality but on its location. 'The going price for average wood stacked where cut in many sections of the State is $\$ 3$ a cord. However, that price is far from universal, and as high as $\$ 5$ a cord or as low as $\$ 2$ are known to have been obtained for the same kind of wood. The price of cutting by the cord, where the chance is good, is usually $\$ 1.50$, but may be less in some sections.

2. Logs. - Oak lumber is in good demand in many sections for furniture, agricultural implements, plumber's woodwork, ship timbers, lobster pots, car stock, vehicles, flooring, dimension timber and planing-mill products. Large logs which will saw fair to good quality lumber can be sold almost anywhere. The value of the lumber delivered on the cars will vary from $\$ 16$ to $\$ 35$ per thousand feet, depending on the quality and use. The usual log lengths are from 10 to 16 feet. It costs more to cut, handle and saw oak than it does pine, so usually saw logs of less than 8 to 10 inches in diameter at the top are not used. Before cutting logs it is usually advisable to see where and at what price they can be sold.

3. Ties. - There is a good demand for cross-ties made of all species of oak. The steam and electric railroad companies buy them. The New Haven road at present buys them in three sizes when hewed on two sides, and without bark; No. 1, 8 feet long, 7 to 12 inch face, $\gamma$ inches thick; No. 2,8 feet long, 6 to 12 inch face, 6 inches thick; No. 3, 8 feet long, 5 to 12 inch face, 6 inches thick. The prices delivered are: No. 1, 70 cents; No. 2, 55 cents; No. 3, 35 cents. The specifications of other companies vary somewhat from these, the street railways usually buying the smaller sizes.

It takes an average $\log$ of $81 / 2$ inches diameter at the small end to make a No. 3 tie. If the $\log$ is orer 15 inches in diameter it has to be hewed or sawed on four sides, for which the specifications are somewhat different.

As a general rule it does not pay to saw the oak into ties, on account of the expense of handling. It can be done profitably under favorable circumstances, but usually ties should be hewed. Hewers can be obtained who will cut and hew for from 12 to 20 cents a tie. 
4. Piling. - Considerable oak piling is used. In the larger sizes - 35 feet long and upward - there is a good demand. The smaller lengths from 16 feet up can be sold, but there is a good deal of risk in cutting them unless a market is obtained beforehand. White oak is the best for piling. No general price for piling can be given, because the distance of haul and expense of handling is such a large factor. From 2 to 6 cents a running foot cut in the woods has been received for the short piles, and as much as $\$ 5$ apiece standing for the big ones.

5. Posts. - In a few places it has been possible to sell white oak posts 6 inches in diameter. With the chestnut going this seems to offer a good field for future development.

6. Other recorded uses are for rustic furniture, fences, baskets and chemical wood.

\section{COST OF THINNING.}

The cost of carrying on a thinning operation depends on the amount of wood to be cut; the amount of brush and its disposal; the size and density of the growth; the severity of the thinning; the efficiency of the labor; and to a lesser degree on the area of the tract, the supervision, the tools and equipment, and other minor factors, as weather conditions, topography, etc.

Figuring of cost should be done on the basis of so much per cord, tie, thousand board feet, etc., rather than so much per acre. Labor should be hired on the cord basis where possible. In light thinnings, in brush cutting, near cities, or for brush disposal it is often impossible to have the work done except by day labor. In places where the labor supply is inadequate it is better to put up a camp and bring in a crew than to use irregular and inefficient local labor.

It must be borne in mind that the per cord cost of thinning is higher than the cost of the ordinary wood chopping. In a thinning only part of the trees are taken, making the felling more difficult, and the work more scattered. Also the poorer and smaller trees are cut and the best ones left, which also adds to the proportionate expense. Usually the owner of the thinned area wants a fairly neat job done, with low stumps and some sort of brush disposal. This adds to the cost. Therefore the owner should undertake these thinnings not to make money, but to keep from losing money through the destruction caused by the moths or the cost of combating them. In fair growth he probably will make a little money, but his largest returns will be in the conservation of what he has. 


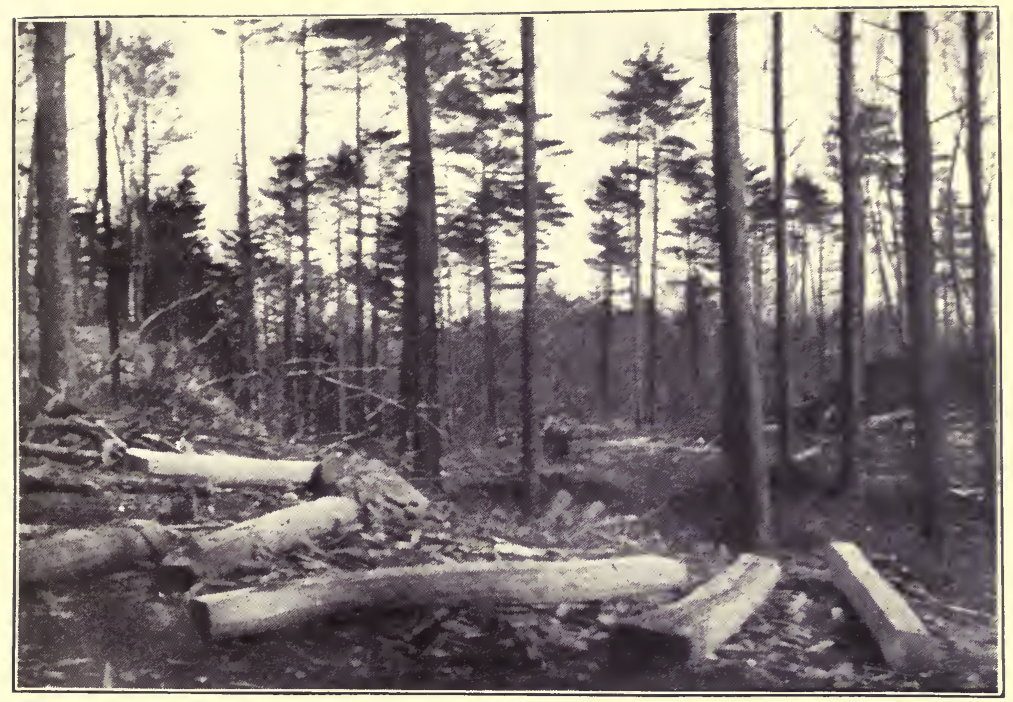

Extreme resistant thinning. All oaks removed and forest cover seriously broken. Natural pine reproduction is expected, which will be followed by the remoral of remaining large trees. Notice the hewed oak ties.

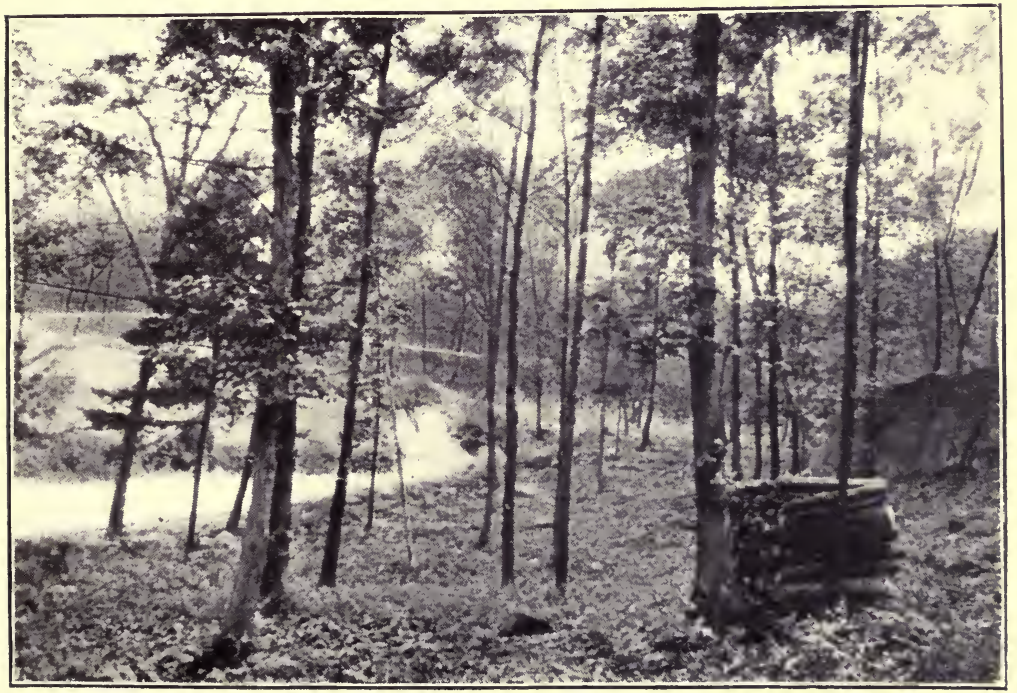

Moderate thinning. All possible nonresistant trees remored, but forest cover not serlously broken. Wood enough cut to pay for the cost of the work. First stage of remaking the stand into a resistant growth if thinning is fcllowed by natural reproluction or by planting of pine. 

However, before undertaking a thinning, with some exceptions, the owner should be assured that he will very nearly "break even," in order to be justified in doing the work.

The following general rules are laid out to enable owners to tell whether a thinning will pay for itself or not:-

1. The thinning should be fairly heavy. At least 7 or 8 cords per acre must usually be cut out to assure financial success.

2. There must not be a large amount of brush to cut.

3. Not very much ornamental work, as limbing up trees that are left, etc., can be done.

4. Large open-grown trees cost more to cut than the wood is worth, also small sprouts.

5. The labor must be efficient. If day labor is employed it should be previously experienced in this kind of work, or its cost will be excessive.

6. Experienced and constant supervision is necessary in an operation of any size to get the best results.

\section{COST DATA.}

In the following tables the costs of thinning operations are analyzed. "Supervision" takes account of the foreman's time when not engaged in productive work, and includes part of the time spent in marking trees for the cutters. "Cutting" includes chopping or sawing down the trees; trimming the branches; cutting tie logs, saw logs and piles, and in one case hewing the ties; and cutting, splitting and piling the cord wood. "Brush disposal" includes cutting the underbrush where necessary, and piling and burning all the rubbish. Where the cost of this item per cord is high, much underbrush was cut; on the job where it was 35 cents per cord, practically all the underbrush was left. "Miscellaneous" includes the foreman's time on rainy days; sharpening saws; time and expenses in moving; and so forth. "Tools" cover the actual cost of depreciation and replacement of the tools used.

In computing the costs per cord it was assumed that tie logs cost 5 cents each to cut; oak saw logs $\$ 2$ per $M$ and pine $\$ 1$; piling 1 cent per running foot; and cedar posts 5 cents each. From these figures was calculated the equivalent in cords of all other products on each job, and the sum of cords and equivalents taken as the total number of cords cut.

Table I. gives the total cost, with the average, high and low cost per cord and per acre of the different items, for six representative 
lots, totalling 191.9 acres, from which were cut 2,121 cords or equivalent. The six taken together give a fair average of the conditions that are likely to be met in thinnings. They do not represent any cuttings in small growth. The average number of cords per acre was 11 ; high, 251/4; low, 7 . On all of these lots the brush was burned and the place cleaned up. Most of the work was done by day labor, but some by the cord. The average result shows a small profit if wood can be sold at $\$ 3$ per cord on the lot, which can be done almost anywhere in the moth-infested region.

TABLe I.

Average of six lots, 191.9 acres, 2,121 cords.

\begin{tabular}{|c|c|c|c|c|c|c|c|c|}
\hline & & \multirow{2}{*}{$\begin{array}{l}\text { Total } \\
\text { Cost. }\end{array}$} & \multicolumn{3}{|c|}{ COST PER CORD. } & \multicolumn{3}{|c|}{ COST PER ACRE. } \\
\hline & & & Average. & High. & Low. & Average. & High. & Low. \\
\hline Supervision, . & 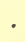 & $\$ 31430$ & \$0 148 & \$0 45 & $\$ 010$ & $\$ 1638$ & $\$ 472$ & $\$ 083$ \\
\hline Cutting, . & . & 4,42957 & 2088 & 242 & 200 & 23083 & 5081 & 1400 \\
\hline Brush disposal, & . & 1,13168 & 534 & 109 & 35 & 5897 & 1135 & 367 \\
\hline Miscellaneous, ${ }^{1}$ & • & 22047 & 143 & 35 & 10 & 2033 & 368 & 118 \\
\hline \multirow[t]{2}{*}{ Tools, } & - & 8091 & 038 & 08 & 03 & 422 & 74 & 27 \\
\hline & & $\$ 6,17693$ & $\$ 2913$ & $\$ 430$ & $\$ 268$ & $\$ 32193$ & $\$ 6816$ & $\$ 1877$ \\
\hline
\end{tabular}

1 Five lots.

Table II. gives the data for a thinning in a 30 to 40 year hardwood stand of medium size. The growth was 80 per cent. of oak with the rest pine and resistant hardwood, mostly maple. A purely resistant cutting was not made, but practically all white oak was taken and enough of the other species were left so that the forest cover was not seriously broken. This thinning is typical of the first stage in the remaking of an oak growth into one of a resistant character. It is expected that the place will be sprayed in the future when necessary, but at a greatly reduced cost over former sprayings. After this thinning, part of the area is ready for underplanting of pine, and part of it has sufficient pine reproduction so that planting will be unnecessary. All oak brush was cut and all brush and slashings burned. This thinning is especially interesting because when the wood is all sold it will have paid for itself and made a small profit, - about $\$ 5$ an acre for the owner. The work was done wholly by experienced day labor under a competent foreman. 



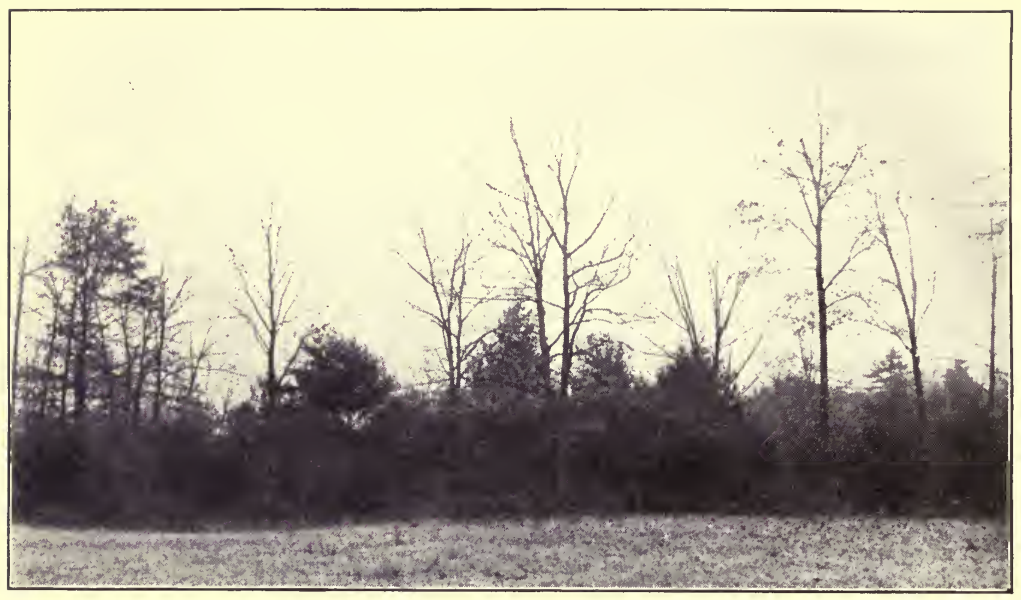

A mixed growth of hard and soft wood that is sure to be destroyed by the gypsy moth unless the owner spends large sums of money in spraying and treating. The only practical forestry solution is to immediately cut out the hard. woods and give the whole area over to the white pine. In an infested stand like this the pines are killed outright in a year or two; therefore, owners having similar woodlands should give them early atteution. The pine in elear stands by itself is perfectly resistant to the moths.

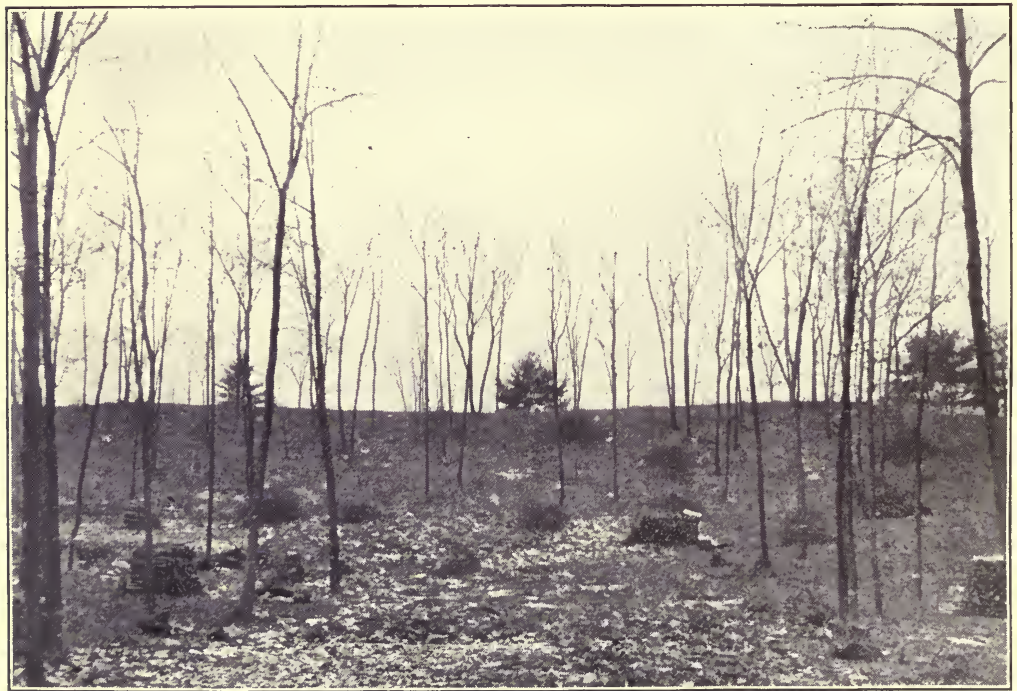

A severe thinning, to be followed by underplanting with white pine. The prod. uet, which was largely white oak, sold for enough to meet the expense. Gypsy moth suppression work on the Karlstein property at Dedham. This property was stripped the past season. 


\section{TABLE II.}

Karlstein, Dedham, 83.5 acres, 579 cords.

\begin{tabular}{|c|c|c|c|c|c|c|c|c|c|}
\hline & & & & & & & Total Cost. & Cost per Cord. & Cost per Acre. \\
\hline Supervision, & . & . & . & . & . & . & $\$ 6830$ & $\$ 012$ & $\$ 083$ \\
\hline Cutting, & • & . & . & . & . & . & 1,15578 & 200 & 1400 \\
\hline Brush disposal, & - & . & . & . & . & . & 30260 & 52 & 367 \\
\hline Tools, . & • & - & . & - & - & - & 2200 & 04 & 27 \\
\hline Total, . & - & . & . & . & . & , & $\$ 1,54865$ & $\$ 268$ & $\$ 1877$ \\
\hline
\end{tabular}

From this lot all the ties have been sold at a price to net $391 / 2$ cents in the $\log (641 / 2$ cents delivered, less 25 cents hewing and hauling); 100 cords of wond have been sold at $\$ 3.35$ on the lot; the rest of the wood, including some of poorer quality, should average at least $\$ 3$. If it fetches $\$ 2.50$, the work will have paid for itself; anything over this will be profit.

Table III. gives the cost data for a cutting operation which represents varied conditions. The main stand, in two lots totalling $221 / 4$ acres, was a growth of large oak with a little pine. The oak had been so seriously damaged that not only was it necessary to clear it off, but also the wood had so deteriorated through the attacks of borers that but little of it could be utilized for anything but cord wood. On one lot of $113 / 4$ acres a sort of thinning was attempted, as it was possible to leave enough maple, pine and other resistant growth to partly cover the ground. The other $101 / 2$ acres were cleaned off of all growth and replanted to pine. On this piece the growth was so heavy in places that as much as 80 cords to the acre were cut, with an average of 45 cords per acre. Besides this main stand there were 6 acres of a young mixed hardwood growth from which all oak and birch was cut, and a larch plantation of 5 acres, which had grown so thick with brush as to be nearly impassable, and which was put into condition. On account of these varied conditions the costs can hardly be called typical, and both the cutting and brush-disposal costs are high, one on account of the large quantity of heavy wood which had to be split, and the other because of the cleaning up in the sprouts and the plantation. Some of the wood was cut by the cord at $\$ 1.50$ per cord and the rest by day labor. These figures are interesting, however, to show that a difficult proposition like this can be made to show a profit. 


\section{TABLE III.}

French lot, North Andover, 33.6 acres, 851 cords.

\begin{tabular}{|c|c|c|c|c|c|c|c|c|c|}
\hline & & & & & & & Total Cost. & Cost per Cord. & Cost per Acre. \\
\hline Supervision, & - & - & - & - & - & - & $\$ 8760$ & $\$ 010$ & $\$ 260$ \\
\hline Cutting, & - & . & - & . & . & . & 1,70966 & 201 & 5081 \\
\hline Brush disposal, & . & . & . & . & - & . & 38171 & 45 & 1135 \\
\hline Miscellaneous, & . & . & . & . & - & . & 8950 & 10 & 266 \\
\hline Tools, . & • & . & - & - & - & . & 2500 & 03 & 74 \\
\hline Total, . & • & . & . & . & - & . & $\$ 2,29347$ & $\$ 269$ & $\$ 3219$ \\
\hline
\end{tabular}

From this lot there have been sold $5 \mathrm{M}$ of oak logs at $\$ 25$ and $14 \mathrm{M}$ of pine at $\$ 12$, delivered at the mill. The ties have been delivered, and should net at least 50 cents on the lot (the cost of hewing is included in "cutting"). Much of the wood has been sold at prices up to $\$ 4$ per cord yarded by the road. The operation, when all the wood is sold, will have paid for itself, paid for planting up the clear-cut area and underplanting part of the thinning, and returned some profit, estimated to be about $\$ 15$ an acre.

In the Schrafft lot in Weston, on about 25 acres, a damage cutting was made where most of the growth (a medium hardwood stand) had been killed a year or two previously, and so the wood was largely dry. Here all the wood was cut by the cord at prices varying from $\$ 1.50$ to $\$ 2$, with an average of $\$ 1.70$ for 570 cords. Most of the brush was burned by the acre at $\$ 5$ to $\$ 6$ per acre, making an average cost of brush disposal of about 25 cents per cord. The supervision cost was 15 cents per cord, making a total cost with tools of about $\$ 2.12$ per cord. This lot is not one of the six averaged in Table I.

\section{CONCLUSION.}

As a forest insect the gypsy moth offers a distinct and important problem. Its extermination can no longer be hoped for. In the woodland its control by shade-tree methods is impracticable on account of expense, if not impossible. It has already been responsible for the destruction of a large part of the growth on hundreds of acres of woodland. Thinnings with the aid of parasites and diseases offer a practical method of combating the moths in forest areas, and an ultimate solution of the woodland problem. The result of these methods will be the replacement of a large part of our oak 
growth with more valuable coniferous stands, for which the land is better suited.

This department is anxious to co-operate with all owners of woodland in the State where moth invasion is present or threatened. Free of all charge they will inspect such woodland with the owners, and offer expert advice as to its condition and treatment. They will also, without expense to the owner, supervise thinning operations, mark trees to be cut, furnish labor and aid in the sale of the wood. If desired this department will take entire management of an operation and see that it is satisfactorily carried on, the owner bearing the actual cost of the work and making any profit that may result.

For aid or advice write to the State Forester. 


\section{REPORT ON THE PRACTICAL THINNING OF A WHITE PINE WOOD LOT.}

INTRODUCTION.

The following report is a record of the conditions and facts connected with the experimental thinning of a white pine woodlot in Warwick, Mass., belonging to Dr. P. W. Goldsbury:-

\section{The Tract.}

The tract extends over an area of 12 acres of gradual swales and ridges at the bottom of a valley. Excepting for a small area where a ledge outcrops or lies very near the surface, the soil is a deep, sandy loam of good moisture, and everywhere well drained.

The stand, which averages fifty years of age, is interrupted by two small ponds from being a block of solid growth. This growth is a result of a natural seeding of an old pasture. As a result of this natural seeding, there are represented two conditions which governed the policy of the thinnings, - the first that of a dense condition where the trees had practically started at the same time and grown up to form an even-aged stand, tall and comparatively clean of their side limbs. A sample plot taken in this condition will better illustrate it:-

Plot $\frac{1}{4}$ Acre, South of Baptism Pond, in Direction of the House.

\begin{tabular}{l|c|c|c|c|c|c|c|c|c|c|c|c|c|c}
\hline & \multicolumn{10}{c}{ Diameter Breast High (Inches). } \\
\hline & 6 & 7 & 8 & 9 & 10 & 11 & 12 & 13 & 14 & 15 & 16 & 17 & 18 & 22 \\
\hline Number of trees, & 3 & 5 & 3 & 9 & 8 & 4 & 7 & 7 & 7 & 3 & 4 & 2 & 2 & 2 \\
\hline
\end{tabular}

A total of 66 trees, or 264 to the acre, with a height of 65 to 70 feet.

Plot $\frac{1}{4}$ Acre, on the Flat between the Two Ponds.

\begin{tabular}{l|c|c|c|c|c|c|c|c|c|c|c|c}
\hline & \multicolumn{7}{c}{ Diameter Breast High (Inches). } \\
\cline { 2 - 9 } & $\mathbf{5}$ & $\mathbf{6}$ & $\mathbf{7}$ & $\mathbf{8}$ & $\mathbf{9}$ & 10 & 11 & $\mathbf{1 2}$ & 13 & $\mathbf{1 4}$ & 15 & 16 \\
\hline Number of trees, & 2 & 3 & 12 & 12 & 13 & 14 & 12 & 6 & 9 & 4 & 3 & 1 \\
\hline
\end{tabular}

A total of 91 trees, or 364 to the acre, with a height of 60 to 70 feet. 


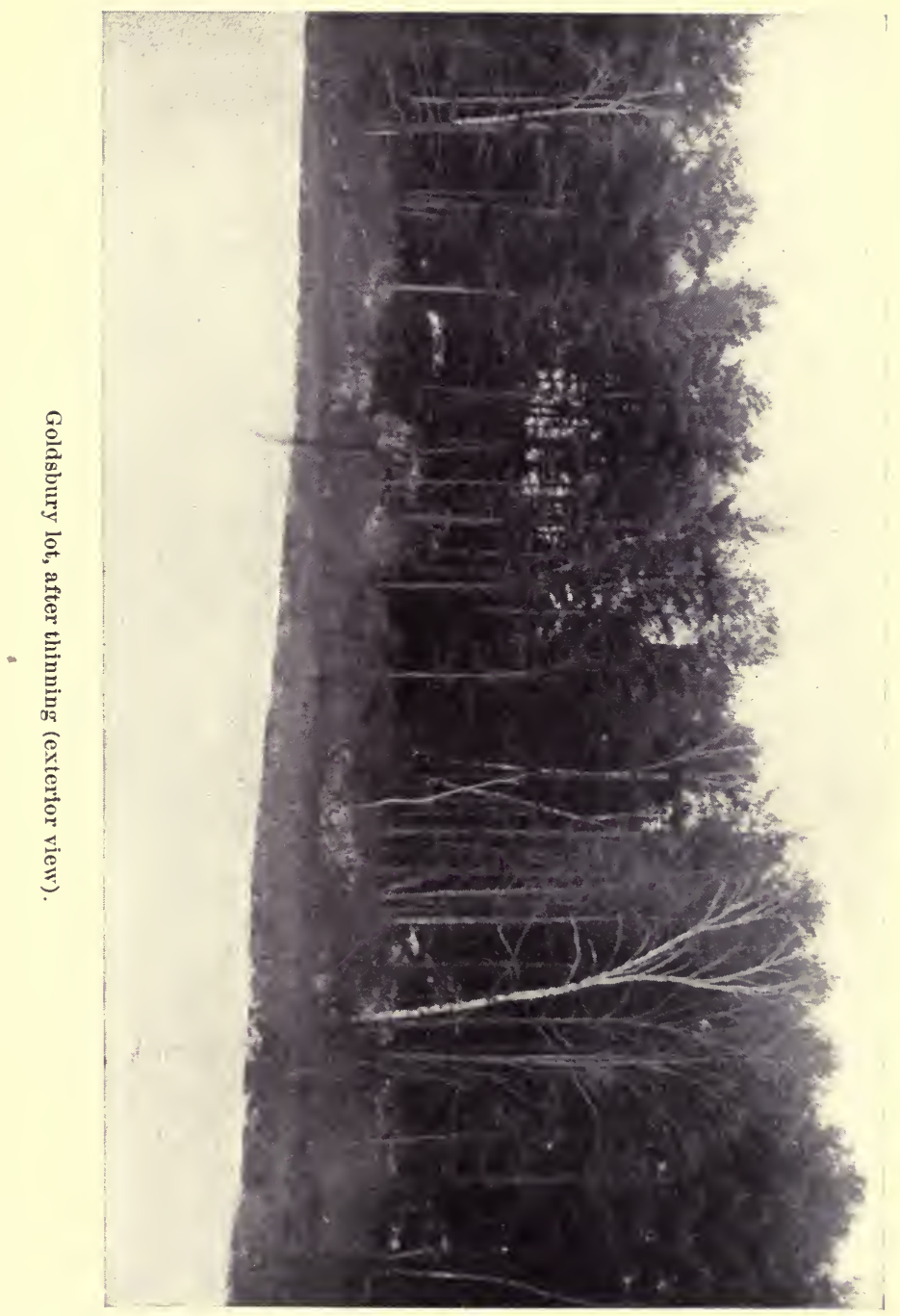



A better idea of the density of these trees can be realized if it is known that 302 trees spaced regularly over an acre would be 12 by 12 feet apart.

The other condition was that where a few trees had started and developed very wide spreading, and with large side limbs near to the ground. The density varied from a condition where the side limbs of the trees came together and completely shaded the ground to where the trees stood with open spots and areas about them. In these open areas there was almost always a good reproduction of white pine coming in among the blueberry, huckleberry and kalmia bushes. The following sample area was taken where the pines had a great deal of room about them, with a good reproduction of pine coming in:-

Plot $\frac{1}{4}$ Acre, Northeast of Large Pond, in Direction of a Field.

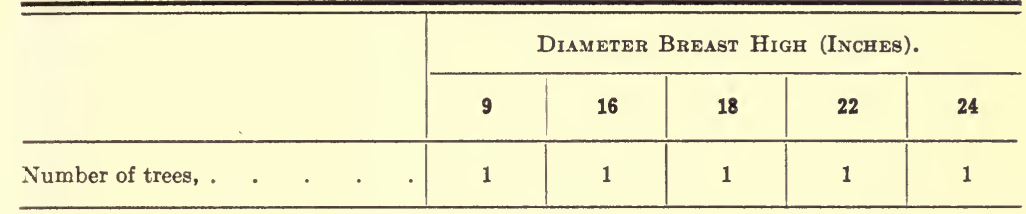

A total of 5 trees, or 20 to the acre, with a height of 55 to 60 feet.

\section{OWNER'S DESIRE.}

It was Dr. Goldsbury's first desire not to mar the beauty of his farm, or to make his woodlot an eyesore to the village of his town by cutting and stripping the land of its fine growth. Furthermore, he desired to take such steps as would improve his lot and place it in a more flourishing condition, so that it would come down to the younger generation unimpaired. Lastly, his difficulty in getting any one to attempt the thinning of his lot influenced him to sacrifice his woodlot to an experiment which would make a basis of calculations for such work in the future.

\section{General Policy.}

For the first condition above mentioned or the even-aged growth, the plan was to thin out the weak and poorer trees, leaving the good specimens with sufficient room for their tops to spread and develop without retardation for some ten years at least. The ground for this policy was based on the fact that the trees had made their main height growth, and their energies were now towards developing their diameters. The growth in diameter of a tree is in proportion to the size of its top, since the leaves are the laboratories of the food material which goes to make up the growth, - the more laboratories the faster the growth.

With this theory in mind, actual practice meant leaving the better and more promising individuals with sufficient room about them to 
allow the tops to grow unchecked for at least ten years. If this is successfully accomplished, the trees will have developed a larger top, more laboratories or a larger feeding area.

The following data show the proportion of trees in number and volume removed and left on the same area:-

\begin{tabular}{|c|c|c|c|c|c|c|c|c|c|c|c|c|c|c|c|c|c|c|}
\hline & \multicolumn{18}{|c|}{ Diameter Breast High (Inches). } \\
\hline & 5 & 6 & 7 & 8 & 8 & 10 & 11 & 12 & 13 & 14 & 15 & 16 & 17 & 18 & 19 & 20 & 21 & 22 \\
\hline Trees removed, & 6 & 17 & 31 & 30 & 38 & 40 & 17 & 18 & 12 & 10 & 3 & - & 2 & 1 & - & - & - & - \\
\hline Trees left, . & 1 & 1 & 3 & 10 & 16 & 32 & 19 & 36 & 36 & 32 & 29 & 24 & 24 & 10 & 4 & 4 & 4 & 1 \\
\hline
\end{tabular}

A total of 225 removed and 286 now standing; in volume (according to Massachusetts volume tables), 27,050 B. M. feet were removed and 50,140 B. M. feet left; in fact, about two-fifths of the trees in number and one-third the volume were taken out in the thinnings.

For the second condition the policy was that of encouraging a natural regeneration where a good reproduction did not exist, and assisting a good reproduction where it did exist. Wherever the trees were close enough together, so as to form a complete shade, certain of the poorer specimens were taken out, allowing light to enter and encouraging the growth of any seedlings.

Wherever a good reproduction had started around or underneath any of these large pines, better known to lumbermen and foresters as the "pasture pines," they were removed, taking care to destroy as few of the smaller or young trees as possible.

Through the entire work there were not any hard-and-set rules which could be followed entirely, for there was here and there a problem which could be decided only on the spot. Around the edges of the stand, thinning if carried on at all was not very heavy, since it was thought that too much sun and wind would be admitted from the sides. The presence of a ledge outcropping and lying very near the surface in one instance resulted in a very light thinning, since it was thought that the stand on it was liable to windfall. Other local problems were treated in like manner, but as a rule the main ideas were not deviated from.

\section{The Operating.}

Every tree to be removed was blazed with a hatchet, in order that the choppers might not make any mistake. In marking, care was necessary in order to mark those with which there would not be any difficulty in felling. Oftentimes it was necessary to remove trees where some difficulty could not be avoided; yet there were also times when a little foresight would obviate any trouble and still allow good specimens 


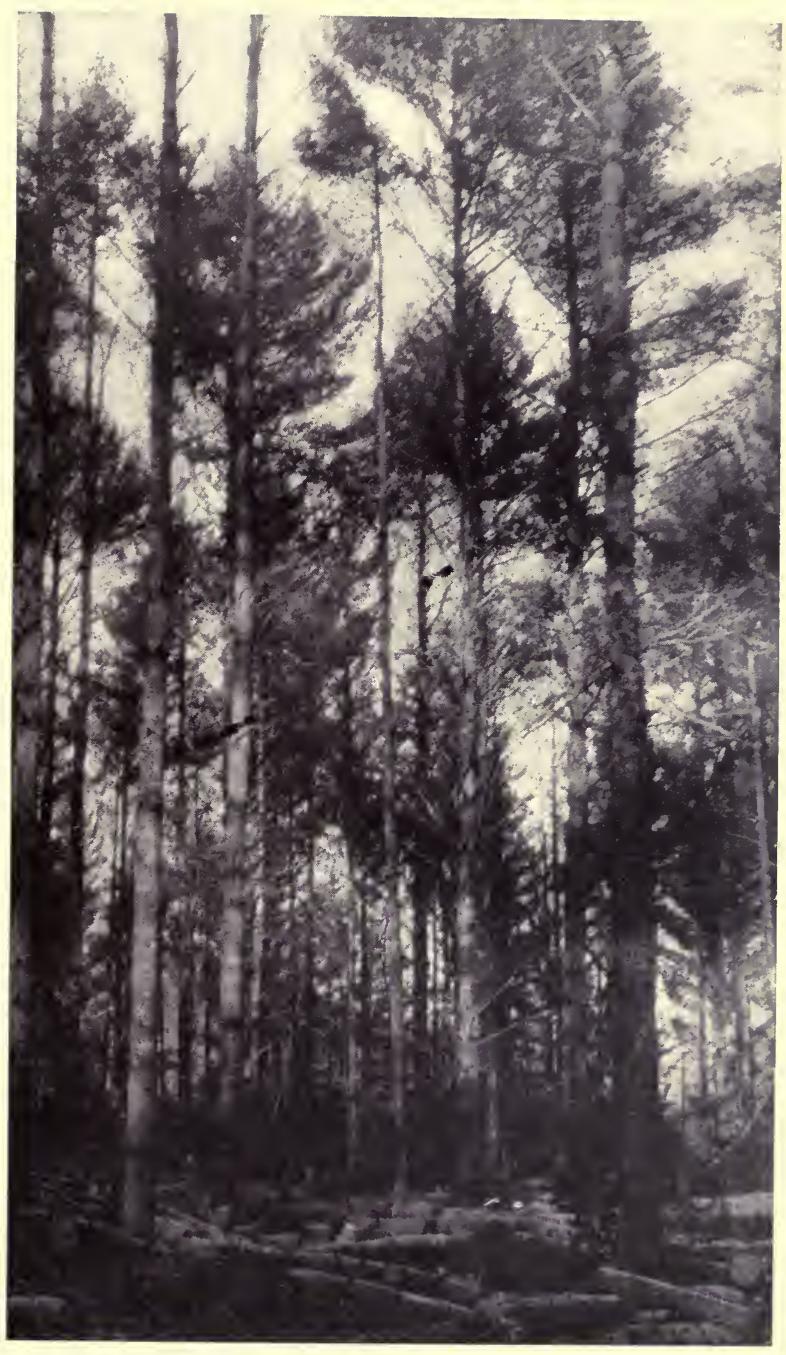

Goldsbury lot, during thinning (interior view). 

to remain. A little time was sufficient to mark an area which would take some time for the choppers to cover.

The choppers were most efficient in gangs of three. One man, going ahead, would under-cut tree just above the ground and on the side towards which it was to fall. It is remarkable to observe the skill some men have in directing the tree through any small opening by the right position of this under-cut on the tree. The other two men following him would saw just above and on the opposite side of the under-cut until the tree fell. It was the first man's duty now to trim the tree of its side branches and mark the tree into logs with lengths most economical for it to be sawed by the other two men.

This system sounds bunglesome to relate, but, once started, one man should not be interrupted or in the way of the others, and under ordinary conditions the work would be about equally portioned.

Frequently a tree was found so wedged in between its neighbors, their limbs interwoven, or so balanced in regard to its necessary felling direction, that some means was required to give the tree a start before it would fall. This was overcome in large trees by wedging the stump and bole in the saw-kerf, or in small trees by directing the men to throw their weight against the tree. Other methods were: picking up small trees and carrying them away at the bole in the opposite direction they were to fall; felling other trees against the one which does not start; and finally, the most useful method, that of turning the tree with a cant-hook, twisting its top in the direction of least support until it gains momentum sufficient to crash to the ground.

The labor of chopping over the 12 acres required seven hundred and forty-eight hours. Over this area many of the so-ealled "pasture pines" were removed, which always tended to make the average cost high, since so much time was required to rid them of their side branches. The fact is that the more expensive trees were removed and the least expensive to handle were left.

Good woodsmen are obtained for $\$ 2$ per day, or for 74.8 days an expense of $\$ 149.60$ over the whole work. The logs were sawed "liverun" into $21 / 8$-inch plank with 1 -inch sidings, and according to the mill scale totalled between $1.25,000$ and 130,000 B. M. feet. Upon the basis of 130,000 feet, the average cost would be $\$ 1.15$ per thousand for the felling and sawing into logs.

The ordinary contracting price when cutting clean is around $\$ 1$ per thousand, - sometimes a little more and sometimes a little less; as a rule, however, a little more, getting as high as $\$ 1.30$ per thousand. The chopping of this lot clean would have cost $\$ 1$ to contract.

Since it was foreseen that the removing of the "pasture pines" was sure to add to the average cost of chopping the improvement thinnings, a record was kept of the labor and the material removed from an area where the work was entirely that of thinning. It required 112.5 hours 
to go over 2.5 acres, where 27,000 feet were removed and 50,000 feet left. At the rate of $\$ 2$ per day, $\$ 22.50$ was the cost of the work of the improvement thinning, or an average of $\$ 0.83$ per thousand by day labor.

The logging of this tract was done upon a low, four-wheeled truck for two horses, since it was found to be more handy in driving about the trees than the ordinary wooden-shod sled or "skid." On snow a traverse sled was used. A few of the trees had to be snaked out with a horse, but ordinarily two men could handle the logs by actually picking them up and carrying them to the sled or truck. The ordinary contracting price for logging this lot would not be over $\$ 1.50$ per thousand, and the additional expense for picking the logs up from among the trees left standing was not over $\$ 0.15$ per thousand.

\section{Conclusion.}

Up to date (December, 1909) there are no bad results in the stand left.

From a practical standpoint there seem to be quite definite conclusions that it is possible to thin out a pine growth fifty years of age with an additional cost of not over $\$ 0.15$ per thousand for chopping and $\$ 0.15$ per thousand for the logging under ordinary conditions.

Joseph J. Dearborn.

AđG. 15, 1908. 


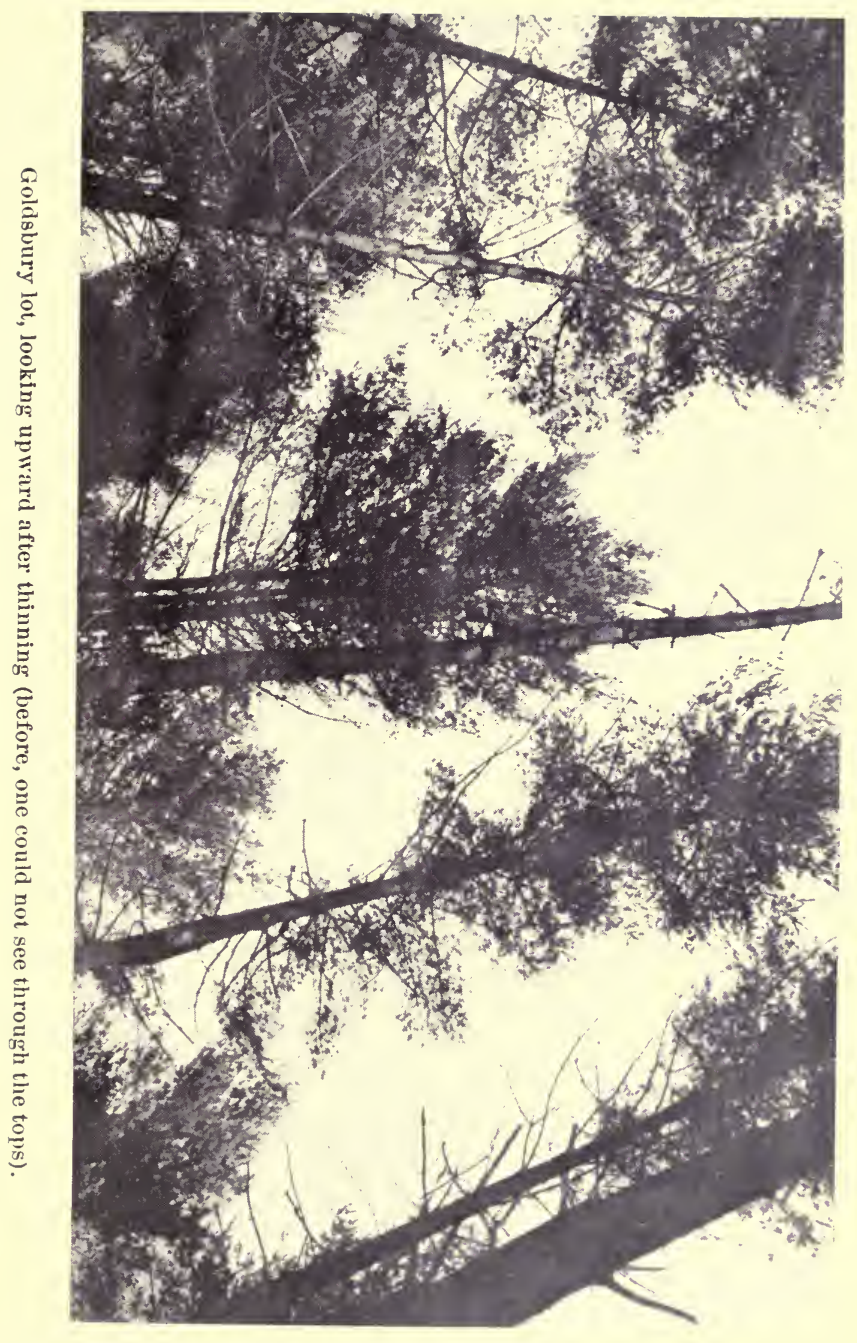





\section{APPLICATION FOR EXAMINATION.}

Should you desire an examination for thinning send to the State Forester for a blank application like the following, fill it out and send it in:-

No.

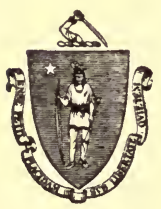

Received................

A P P L I C A T I O N

FOR AN

\section{EXAMINATION OF FOREST LANDS}

то тне

MASSACHUSETTS STATE FORESTER,

6 BEACON STREET, BOSTON.

The State Forester stands ready at all times to promote the perpetuation, extension and proper management of the forest lands of the Commonwealth, both public and private (1904, chapter 409, section 2).

If you have such lands and desire an examination of them and advice as to their management, fill out the following blank form and send it to the above address of State Forester.

Upon receipt, this request will be placed on file, and you will be informed, in order of application, approximately when the examination ean be made, and a mutual date can then be decided upon.

The only expense the applicant promises to pay is that of travel and subsistence of the State Forester or his assistants, incurred in making the examination.

It is always more satisfactory to personally meet on the property the owner or party most interested, at least when the preliminary examination is made. In this way a definite understanding ean be had as to future undertakings, and whether working plans are necessary. Often a preliminary visit to gain knowledge of the problem and give advice on the grounds are all the services needed.

When sending this application in, a brief description of the land will assist us.

With the above understanding, I desire to have an examination made

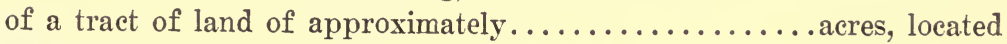

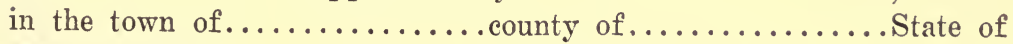
Massachusetts.

Signed

Address

Date................19 





is

ㄱำ

1948

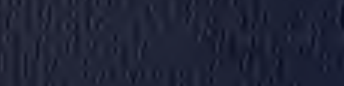

4.

8.

is: 